\title{
Landslide prediction capability by comparison of frequency ratio, fuzzy gamma and landslide index method
}

\author{
Mahvash Gholami ${ }^{1}$, Esmaeil Nekouei Ghachkanlu ${ }^{2}$, Khabat Khosravi $^{3}$ \\ and SAied Pirasteh ${ }^{4, *}$ \\ ${ }^{1}$ Department of Watershed Management Engineering, College of Natural Resources and Marine Sciences, \\ Tarbiat Modares University, Noor, Iran. \\ ${ }^{2}$ Department of Earth Sciences, College of Sciences, Shiraz University, Shiraz, Iran. \\ ${ }^{3}$ Department of Watershed Management Engineering, Sari Agricultural Science and Natural Resources University, \\ Sari, Iran. \\ ${ }^{4}$ Department of Surveying and Geoinformatics, Faculty of Geosciences and Environmental Engineering (FGEE), \\ Southwest Jiaotong University, Chengdu, China. \\ ${ }^{*}$ Corresponding author. e-mail: moshaver1380@gmail.com
}

MS received 15 September 2017; revised 25 January 2018; accepted 26 April 2018; published online 8 February 2019

This study presented the prediction capability of three methods including the frequency ratio (FR), fuzzy gamma (FG) and landslide index method (LIM) to produce landslide-prone areas in the Sari-Kiasar watershed, Mazandaran Province of Iran. In the first step, 105 landslide locations were selected and were randomly divided into two groups of $75 \%$ (78 locations) and 25\% (27 locations) as training and testing datasets. Then the 17 landslide conditioning factors including land use/land cover, Differential Vegetation Index (DVI), lithology and distance from faults, elevation, slope aspect, slope angle, tangential curvature, profile curvature and plane curvature, distance from drainage, rainfall, Stream Power Index, Sediment Transport Index and temperature, and distance from road, density of settlement were considered for the proposed modelling approach. Finally, by applying the training dataset, three landslide susceptibility maps were constructed by using the FR, FG and LIM methods. The prediction capability of the performed model was evaluated by the area under the receiver operating curve or AUC for both training (success rate) and testing (prediction rate) datasets. The results showed that the AUC for success rate of FR, FG and LIM models was $82.04 \%, 81.08 \%$ and $73.61 \%$ and for prediction rate was $82.72 \%, 79.09 \%$ and $65.45 \%$, respectively. The results showed that the FR model has a higher prediction accuracy than the FG and LIM methods. This study revealed that the most important factors in landslide occurrence are rainfall, slope and vegetation. The result of the present study can be possibly useful for land use planning and watershed management.

Keywords. Landslide susceptibility; FR; fuzzy gamma; LIM; Sari-Kiasar.

\section{Introduction}

Landslides are one of the common natural hazards in hilly and mountainous areas. All through the world, landslides have negative effects on human life and financial movement (Pourghasemi et al. 2012a,b; Pirasteh and Li 2016; Ye et al. 2016; Li et al. 2017; Pirasteh et al. 2017). Population growth and the improvement of fundamental structures and lines (water, power, gas, oil, etc.) in 
unsafe areas bring the expanding effect of natural disasters in developing and developed nations (Rosenfeld 1994). Landslides cause damage to natural resources, development projects, human life and property. According to the Iranian Landslide working Party (2007), about 187 people were killed and losses were estimated at about 12,700 dollars. Because of the complex nature of natural hazards, e.g., landslides, current scientific innovations are not able to predict these events completely. The dominant part of local and regional authorities and land use organisers are compelled to elude landslide susceptibility maps (LSM). Extensive mapping on a substantial scale of a number of landslides perhaps is not possible because of the remoteness of the area and the constraint on spending, and this is a debatable issue. The number of landslides have been increased due to the climate change, deforestation, unplanned urbanisation, etc. (Yusof et al. 2011; Pourghasemi et al. 2012a, b; Pirasteh et al. 2017). Thus, one of the most important actions of reduction of landslide hazards is the identification of landslide-prone areas through LSM by different methods.

Many researchers have used GIS and remote sensing for the identification of landslide-prone areas (Farrokhnia et al. 2011; Pirasteh and $\mathrm{Li}$ 2016). Methods of landslide hazard modelling are divided into two main categories: qualitative methods (landslide inventories and heuristic analysis) and quantitative methods (statistical analysis, probabilistic prediction analysis and deterministic analysis) (Glade and Crozier 2005). Many landslide studies are carried out by using GIS, and some of these studies have applied probabilistic models such as frequency ratio (FR), fuzzy logic (Akgun and Bulut 2007; Akgun and Turk 2010; Pradhan et al. 2010; Yalcin et al. 2011; Tien Bui et al. 2012; Ozdemir and Altural 2013; Park et al. 2013; Regmi et al. 2013; Hong et al. 2015; Khosravi et al. 2016a; Pirasteh and Li 2017a,b), landslide index method (LIM) approach (Ozdemir and Turoglu 2007; Ruff and Czurda 2008; Santos 2013) and machine learning models (Hong et al. 2015; Pham et al. 2017). The bivariate models benefit from some advantages such as (i) they are simpler than the machine learning models, (ii) do not use the expert knowledge which is the source of uncertainty and bias, (iii) have a reasonable accuracy and sometimes more than the machine learning models (Khosravi et al. 2016a,b; Rahmati and Pourghasemi 2017) and (iv) relationships between landslide occurrences and each class of each factor can be determined easily.

The aim of the present study is the preparation of LSM by using FR, an ensemble of FR with fuzzy gamma (FG) and LIM at the Sari-Kiasar watershed in Iran as a hotspot area in a landslide occurrence.

\section{Description of the study area}

The Sari-Kiasar watershed has an area of about $800 \mathrm{~km}^{2}$ and is located in the upper east of Alborz mountains in northern Iran, south of Sari city and lies between $36^{\circ} 09^{\prime} 56^{\prime \prime}-36^{\circ} 29^{\prime} 24^{\prime \prime} \mathrm{N}$ and $53^{\circ} 0^{\prime} 27^{\prime \prime}-$ $53^{\circ} 24^{\prime} 18^{\prime \prime} \mathrm{E}$ (figure 1). The elevation of the study area varies from 97 in the plain to $1670 \mathrm{~m}$ above m.s.l. on mountain area. The main units of lithology in this region consist of limestone, dolomite, shale, siltstone, sandstone, marl, tuff, conglomerate, anhydrite, salt and their different combination (tables 1 and 3). The land use/land cover (LULC) of the study area is including 10 units (tables 2 and 3 ). The normal temperature in the study area is from $12.41^{\circ}$ to $14.48^{\circ} \mathrm{C}$. The mean annual precipitation in the study area varies between $339 \mathrm{~mm}$ in lowlands and $607 \mathrm{~mm}$ over the highlands (Meteorological Organization of Mazandaran Province 2013) (table 3).

\section{Data preparation}

\subsection{Landslide inventory map}

The existing landslide inventory map is very essential for studying the spatial relationship between the landslide occurrence and the conditioning factors (Pourghasemi et al. 2013). In the present study, the landslide inventory map was recorded and mapped by extensive field survey and utilising 1:25,000 scale aerial photographs (Geological Survey of Iran). Finally 105 landslides have been recognised which occurred from the past up to 2016. Then, landslide locations are divided into two parts randomly. Of that 78 locations, $75 \%$ for training the models or model building and the remaining $(25 \%)$ were utilised for validation of the purposes (Hong et al. 2015; Vakhshoori and Zare 2016). Based on the movement typology, utilising a streamlined order of Varnes (1978), the landslides were grouped into rotational or translational slides (71 bodies) and complex slides (34 bodies) (figure 2 ). 


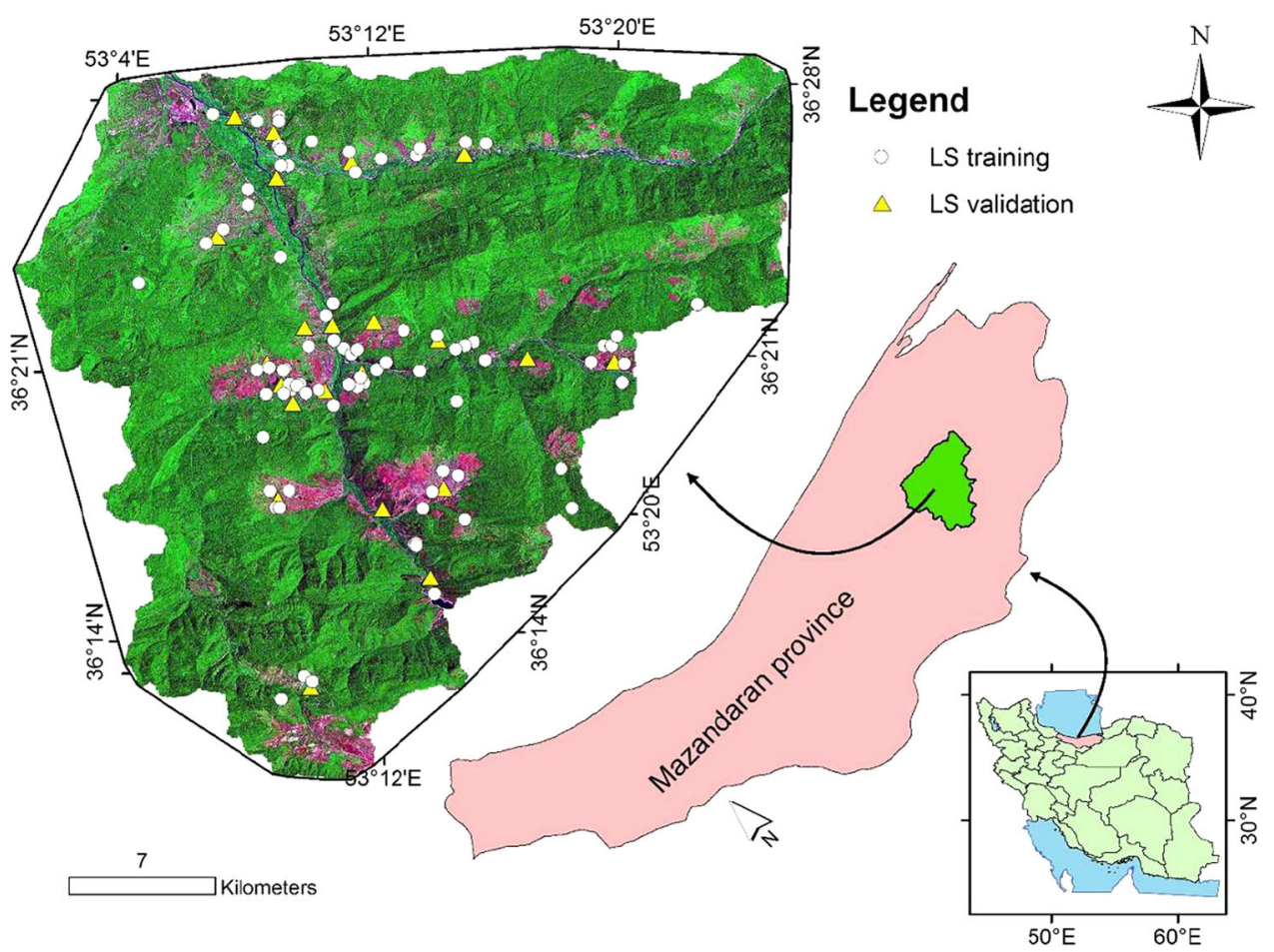

Figure 1. The study area location in Iran and landslide inventory map of the Sari-Kiasar watershed (yellow points are landslide points for validation of the model and the white points are for training).

\subsection{Landslide conditioning factors}

There are no universal guidelines regarding the selection of factors in landslide susceptibility mapping (Ayalew et al. 2005). The selection of conditioning factors needs to take the characteristics of the study area and data availability into account (Khosravi et al. 2016a). Based on the literature review, the study area condition and data availability (Althuwaynee et al. 2014; Hong et al. 2015; Sahin et al. 2015; Barrile et al. 2016), 17 conditioning factors have been identified which are practical and applicable for the study area including: geological factors (lithology, distance from faults, LULC and Differential Vegetation Index (DVI)), geomorphological factors (elevation, slope aspect, slope angle, tangential curvature, profile curvature and plane curvature), hydrological factors (distance from drainage, rainfall, Stream Power Index (SPI), Sediment Transport Index (STI) and temperature), and anthropogenic factors (distance from road, density of settlement).

The distance from drainage, SPI, STI, elevation, slope aspect, slope angle, curvature, profile curvature and plane curvature have been derived from the digital elevation model (DEM), using ArcGIS10.1 and SAGA GIS 2 software. The DEM was downloaded from the ASTER Global DEM (https://gdex.cr.usgs.gov/gdex/) with $30 \times 30 \mathrm{~m}$ pixel size. The remaining landslide conditioning factors after preparation were changed to the raster format with $30 \times 30 \mathrm{~m}$ in pixel size (figure 3 ).

\subsubsection{Geomorphological factors}

The geomorphological factors applied in this study including elevation, slope angle, slope aspect, curvature, profile curvature and plane curvature have been constructed directly from the DEMs (figure 3).

Elevation: The elevation is one of the important factors that has been utilised in landslide susceptibility analysis (Cevik and Topal 2003; Caniani et al. 2008; Raghuvanshi et al. 2015). The elevation of the study area varies from $97 \mathrm{~m}$ in the plain to $1670 \mathrm{~m}$ above m.s.l. on mountain zones. For the present study, the elevation map has been constructed and divided into seven classes includes lower than 100, 100-300, 300-600, 600-900, 9001100, 1100-1300 and >1300 m (Raghuvanshi et al. 2015) (figure 3a).

Slope: The slope angle is the primary factor impacting slope instability (Saha et al. 2002; Yalcin 2008; Raghuvanshi et al. 2015). As the slope 


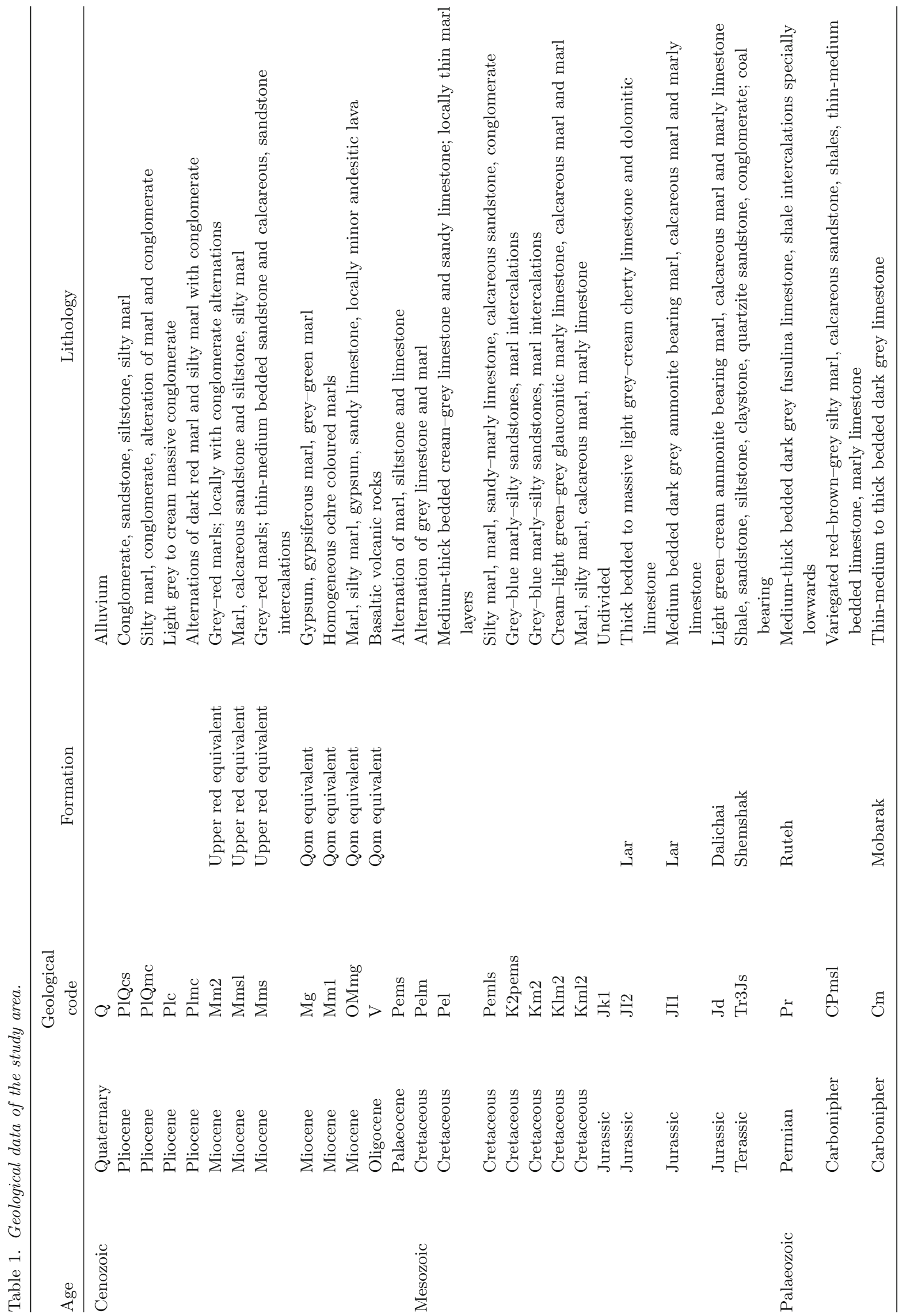


Table 2. Land cover types of the study area.

\begin{tabular}{llc}
\hline $\begin{array}{l}\text { Land cover } \\
\text { code }\end{array}$ & \multicolumn{1}{c}{$\begin{array}{c}\text { Description } \\
\text { O }\end{array}$} & $\begin{array}{c}\text { Area } \\
\left(\mathrm{km}^{2}\right)\end{array}$ \\
F1 & Trees and garden plants & 3.15 \\
IO & Dense forest lands & 548.773 \\
F2 & Blended agriculture and gardens & 7.121 \\
I1 & Semi-dense forest lands & 1.5 \\
U1 & Irrigated agriculture & 44.305 \\
OI & Residential area & 1.586 \\
FO & Garden blend and agriculture & 47.906 \\
DF & Blended forests and orchards & 71.766 \\
\hline
\end{tabular}

angle increases, shear stress in the soil or other un-consolidated material generally increases (Ahmed 2009). The slope degree in the SariKiasar watershed varies from 0 to $79^{\circ}$. For the present study, the slope angle was subdivided into 7 classes: $0-6^{\circ}, 6-12^{\circ}, 12-18^{\circ}, 18-24^{\circ}, 24-30^{\circ}$, $30-40^{\circ}$ and higher than $40^{\circ}$ (Althuwaynee et al. 2014) (figure 3b).

Slope aspect: The aspect is viewed as a pertinent factor for precariousness since it controls some climatic parameters, e.g., moisture and soil temperature due to solar radiation (Yilmaz 2009; Conforti et al. 2013). The amount of rainfall on a slope may also vary depending on its aspect (Raghuvanshi et al. 2015). This study produced thematic maps including slope aspect. The slope aspect map is divided into nine classes which incorporate with flat class, north, south, east, and west. These classes are based on the principle directions (Shahabi et al. 2014) (figure 3d).

Curvature: The surface curvature at a point is the curvature of a line formed by the intersection of the surface with a plane with a specific orientation, passing through this point (Evans 1979; Zevenbergen and Thorne 1987; Wilson and Gallant 2000). The curvature or slope shape has three categories: concave (negative values), convex (positive values) and flat (zero value). Stocking (1972) expressed that convex slopes are more stable than concave slopes, because runoff disperses equally and easily down the convex slopes. Concave slopes, which have a tendency to hold moisture, are prone to landslides (Sujatha et al. 2012).

Plane curvature: The plane curvature is the curvature in a horizontal plane (Crosby 2006). The plane curvature is positive for cells with convex contours and negative for cells with concave contours (Crosby 2006). In particular, the plane curvature controls the convergence or divergence of water in the direction of landslide motion (Carson and Kirkby 1972). In the study area, plane curvature was subdivided into three classes: lower than $-0.01,-0.01$ to 0.006 and higher than 0.006 (Ozdemir and Turoglu 2007) (figure 3l) and both the concave and convex slopes highlight a fairly homogeneous distribution while the $55.76 \%$ of the Sari-Kiasar catchment falls in the flat area.

Profile curvature: The profile curvature is the curvature of the surface in the direction of the steepest slope (in the vertical plane of a flow line) (Ayalew et al. 2004). The profile curvature affects the flow velocity of water draining the surface and influences the erosion and deposition (Zevenbergen and Thorne 1987). For the present study, the profile curvature was divided into three classes: lower than $-0.01,-0.01$ to 0.006 and higher than 0.006 (Ozdemir and Turoglu 2007) (figure 3k).

General curvature: The general curvature (also called total curvature or standard curvature) combines both the profile and plane curvatures (Zevenbergen and Thorne 1987). The general curvature can be positive or convex (indicating peaks), negative or concave (indicating valleys) or zero (indicating flat surface) (Zevenbergen and Thorne 1987). For the present study, the general curvature was divided into three classes: lower than -0.01 , -0.01 to 0.006 and higher than 0.006 (Ozdemir and Turoglu 2007) (figure 3j).

\subsubsection{Geological factors}

Lithology: This factor shows the physical characteristics of the rock. Different lithological units have a different infiltration. The 28 distinctive lithological units in the study area were digitised from 1:250,000 scale geology maps arranged by the Geological Survey of Iran (GSI) (figure 3q). The main units of lithology in this region consist of limestone, dolomite, shale, siltstone, sandstone, marl, tuff, conglomerate, anhydrite, salt and their different combinations.

Distance from fault: Discontinuity of rock and soil as a fault is the principal factor affecting landslides (Wu et al. 2014; Raghuvanshi et al. 2015). More distance from the fault has the lower landslide occurrences probability (Shahabi et al. 2014). In the present study, the distance from the 
Table 3. The results of FR, FG $(\gamma=0.975)$ and LIM models for spatial relationship between factors and landslide.

\begin{tabular}{|c|c|c|c|c|c|}
\hline Class & Class \% & $\begin{array}{c}\text { Landslide } \\
(\%)\end{array}$ & $\begin{array}{c}\text { FR } \\
\text { value }\end{array}$ & $W i$ & $\begin{array}{c}\text { Fuzzy } \\
\text { membership }\end{array}$ \\
\hline \multicolumn{6}{|c|}{ Elevation (m) } \\
\hline$<100$ & 0.01 & 0.000 & 0.00 & 0.00 & 0.00 \\
\hline $100-300$ & 9.78 & 22.890 & 2.34 & 0.85 & 1.00 \\
\hline $300-600$ & 36.83 & 56.620 & 1.53 & 0.42 & 0.65 \\
\hline $600-900$ & 34.96 & 13.250 & 0.38 & -0.96 & 0.16 \\
\hline $900-1100$ & 11.32 & 0.000 & 0.00 & 0.00 & 0.00 \\
\hline $1100-1300$ & 4.71 & 3.610 & 0.76 & -0.27 & 0.32 \\
\hline$>1300$ & 2.36 & 0.000 & 0.00 & 0.00 & 0.00 \\
\hline \multicolumn{6}{|c|}{ Slope aspect } \\
\hline Flat & 10.30 & 10.840 & 1.05 & 0.05 & 0.47 \\
\hline North & 18.39 & 13.250 & 0.72 & -0.32 & 0.19 \\
\hline Northeast & 5.41 & 3.610 & 0.66 & -0.4 & 0.14 \\
\hline East & 15.79 & 12.040 & 0.76 & -0.27 & 0.22 \\
\hline Southeast & 5.49 & 8.430 & 1.53 & 0.42 & 0.89 \\
\hline South & 14.49 & 24.090 & 1.66 & 0.5 & 1.00 \\
\hline Southwest & 5.02 & 6.020 & 1.19 & 0.18 & 0.59 \\
\hline West & 17.89 & 18.070 & 1.01 & 0.01 & 0.44 \\
\hline Northwest & 7.17 & 3.610 & 0.50 & -0.68 & 0.00 \\
\hline \multicolumn{6}{|l|}{ SPI } \\
\hline$>10$ & 35.50 & 28.916 & 0.81 & -0.2 & 0.003 \\
\hline $10-20$ & 13.85 & 12.048 & 0.87 & -0.13 & 0.04 \\
\hline $20-30$ & 7.14 & 13.253 & 1.86 & 0.62 & 0.74 \\
\hline $30-40$ & 4.42 & 3.614 & 0.82 & -0.2 & 0.006 \\
\hline $40-50$ & 3.25 & 7.229 & 2.23 & 0.8 & 1.00 \\
\hline$>50$ & 35.85 & 34.940 & 0.97 & -0.02 & 0.11 \\
\hline \multicolumn{6}{|c|}{ Distance from drainage (m) } \\
\hline $0-100$ & 15.92 & 30.120 & 1.89 & 0.63 & 1.00 \\
\hline $100-200$ & 12.60 & 18.070 & 1.43 & 0.36 & 0.75 \\
\hline $200-400$ & 22.18 & 26.500 & 1.19 & 0.17 & 0.62 \\
\hline $400-700$ & 21.98 & 18.070 & 0.82 & -0.19 & 0.43 \\
\hline $700-1000$ & 11.55 & 6.020 & 0.52 & -0.65 & 0.27 \\
\hline $1000-1500$ & 9.69 & 1.200 & 0.12 & -2.08 & 0.06 \\
\hline$>1500$ & 6.05 & 0.000 & 0.00 & 0.00 & 0.00 \\
\hline \multicolumn{6}{|c|}{ Dist. faults (m) } \\
\hline $0-200$ & 27.71 & 25.300 & 0.91 & -9.1 & 0.30 \\
\hline $200-400$ & 21.09 & 24.090 & 1.14 & 13.5 & 0.66 \\
\hline $400-600$ & 15.88 & 13.250 & 0.83 & -18.1 & 0.17 \\
\hline $600-1000$ & 18.64 & 25.300 & 1.35 & 30.5 & 1.00 \\
\hline$>1000$ & 16.71 & 12.040 & 0.72 & -32.7 & 0.00 \\
\hline \multicolumn{6}{|c|}{ Slope degree } \\
\hline $0-6$ & 25.98 & 25.30 & 0.97 & -0.02 & 0.600 \\
\hline $6-12$ & 18.83 & 19.27 & 1.02 & 0.02 & 0.725 \\
\hline $12-18$ & 20.27 & 20.48 & 1.01 & 0.01 & 0.700 \\
\hline $18-24$ & 14.86 & 16.86 & 1.13 & 0.12 & 1.000 \\
\hline $24-30$ & 9.88 & 7.22 & 0.73 & -0.31 & 0.000 \\
\hline $30-40$ & 7.96 & 8.43 & 1.06 & 0.05 & 0.825 \\
\hline$>40$ & 2.18 & 2.41 & 1.1 & 0.09 & 0.925 \\
\hline
\end{tabular}


Table 3. (Continued.)

\begin{tabular}{|c|c|c|c|c|c|}
\hline Class & Class \% & $\begin{array}{c}\text { Landslide } \\
(\%)\end{array}$ & $\begin{array}{c}\mathrm{FR} \\
\text { value }\end{array}$ & $W i$ & $\begin{array}{c}\text { Fuzzy } \\
\text { membership }\end{array}$ \\
\hline \multicolumn{6}{|c|}{ Lithology code } \\
\hline $\mathrm{Cm}$ & 0.10 & 0.00 & 0.00 & 0.00 & 0.00 \\
\hline CPmsl & 0.18 & 1.20 & 6.74 & 1.9 & 1.00 \\
\hline $\mathrm{Jd}$ & 0.06 & 0.00 & 0.00 & 0.00 & 0.00 \\
\hline $\mathrm{JKl}$ & 0.31 & 0.00 & 0.00 & 0.00 & 0.00 \\
\hline $\mathrm{Jl1}$ & 0.24 & 0.00 & 0.00 & 0.00 & 0.00 \\
\hline $\mathrm{J} 12$ & 0.28 & 0.00 & 0.00 & 0.00 & 0.00 \\
\hline K2Pems & 0.33 & 0.00 & 0.00 & 0.00 & 0.00 \\
\hline $\mathrm{K} \operatorname{lm} 2$ & 4.90 & 2.41 & 0.49 & -0.7 & 0.07 \\
\hline $\mathrm{Km} 2$ & 1.61 & 1.20 & 0.75 & -0.29 & 0.11 \\
\hline $\mathrm{Kml} 2$ & 2.50 & 1.20 & 0.48 & -0.72 & 0.07 \\
\hline $\mathrm{Mg}$ & 0.04 & 0.00 & 0.00 & 0.00 & 0.00 \\
\hline $\mathrm{Mm} 1$ & 0.64 & 2.41 & 3.78 & 1.32 & 0.56 \\
\hline $\mathrm{Mm} 2$ & 5.52 & 0.00 & 0.00 & 0.00 & 0.00 \\
\hline Mms & 4.76 & 2.41 & 0.51 & -0.68 & 0.07 \\
\hline Mmsl23 & 57.99 & 45.78 & 0.79 & -0.23 & 0.11 \\
\hline OMmg1 & 0.53 & 0.00 & 0.00 & 0.00 & 0.00 \\
\hline Pel & 4.46 & 6.02 & 1.35 & 0.3 & 0.2 \\
\hline Pelm & 1.02 & 0.00 & 0.00 & 0.00 & 0.00 \\
\hline Pemls & 3.13 & 0.00 & 0.00 & 0.00 & 0.00 \\
\hline Pems & 0.58 & 0.00 & 0.00 & 0.00 & 0.00 \\
\hline Plc & 0.54 & 0.00 & 0.00 & 0.00 & 0.00 \\
\hline Plmc & 0.12 & 0.00 & 0.00 & 0.00 & 0.00 \\
\hline PlQcs & 4.26 & 20.48 & 4.81 & 1.57 & 0.71 \\
\hline PlQmc & 0.65 & 0.00 & 0.00 & 0.00 & 0.00 \\
\hline $\operatorname{Pr}$ & 0.18 & 0.00 & 0.00 & 0.00 & 0.00 \\
\hline $\mathrm{Q}$ & 4.79 & 16.87 & 3.52 & 1.26 & 0.52 \\
\hline TR3Js & 0.13 & 0.00 & 0.00 & 0.00 & 0.00 \\
\hline $\mathrm{V}$ & 0.15 & 0.00 & 0.00 & 0.00 & 0.00 \\
\hline \multicolumn{6}{|l|}{ DVI } \\
\hline$<30$ & 7.57 & 24.10 & 3.18 & 1.15 & 0.88 \\
\hline $30-60$ & 11.12 & 39.76 & 3.57 & 1.27 & 1.00 \\
\hline 60-90 & 71.35 & 33.73 & 0.47 & -0.75 & 0.07 \\
\hline$>90$ & 9.95 & 2.41 & 0.24 & -1.4 & 0.00 \\
\hline \multicolumn{6}{|c|}{ Settlement density } \\
\hline Very low & 73.6 & 39.760 & 0.54 & -0.61 & 0.16 \\
\hline Low & 18.3 & 38.550 & 2.10 & 0.74 & 0.64 \\
\hline Mod. low & 5.57 & 18.070 & 3.24 & 1.17 & 1.00 \\
\hline Moderate & 1.82 & 3.610 & 1.98 & 0.68 & 0.61 \\
\hline Mod. high & 0.51 & 0.000 & 0.00 & 0.00 & 0.00 \\
\hline High & 0.03 & 0.000 & 0.00 & 0.00 & 0.00 \\
\hline Very high & 0.00 & 0.000 & 0.00 & 0.00 & 0.00 \\
\hline \multicolumn{6}{|l|}{ Land use } \\
\hline DF & 9.16 & 21.680 & 2.36 & 0.86 & 0.38 \\
\hline $\mathrm{FO}$ & 8.97 & 7.230 & 0.80 & -0.21 & 0.13 \\
\hline I1 & 5.53 & 8.430 & 1.52 & 0.42 & 0.24 \\
\hline $\mathrm{IO}$ & 0.89 & 3.610 & 4.05 & 1.4 & 0.65 \\
\hline $\mathrm{O}$ & 0.39 & 2.410 & 6.18 & 1.81 & 1.00 \\
\hline $\mathrm{F} 1$ & 68.5 & 31.320 & 0.45 & -0.78 & 0.07 \\
\hline OI & 5.99 & 25.300 & 4.22 & 1.44 & 0.68 \\
\hline
\end{tabular}


Table 3. (Continued.)

\begin{tabular}{lccccc}
\hline Class & Class\% & $\begin{array}{c}\text { Landslide } \\
(\%)\end{array}$ & $\begin{array}{c}\text { FR } \\
\text { value }\end{array}$ & Wi & $\begin{array}{c}\text { Fuzzy } \\
\text { membership }\end{array}$ \\
\hline U1 & 0.19 & 0.000 & 0.00 & 0.00 & 0.00 \\
F2 & 0.18 & 0.000 & 0.00 & 0.00 & 0.00
\end{tabular}

Plane curv.

$<-0.01$

21.89

20.48

55.76

59.03

20.48

\subsection{6}

0.94

0.92

0.05
0.00

0.11

$>0.006$

22.35

42.17

7.229

50.602

0.93

$-0.07$

$-0.01-0.006$

10.3

0.70

$-0.35$

0.13

1.00

$>0.006$

44.4

1.14

0.00

0.00

0.00

$-0.84$

$-0.37$

0.23

0.35

$-0.02$

$13.2-13.6$

5.56

2.41
25.30

0.43

1.26

1.43

0.53

61.44

$14.4-14.8$

7.57
-4.47

10.84

Dist. from road (m)

0-100

100-200

200-300

300-400

400-500

$>500$

Rainfall (mm)

$<400$

400-450

450-500

500-550

550-600

$>600$

14.0

10.7

7.87

10.4

7.20

49.6

27.71

19.27

16.86

14.45

7.23

14.45

2.25

7.93

28.22

38.73

22.00

0.86

STI

0-10

10-20

20-30

30-40

$40-50$

$50-60$

$60-70$

$70-80$

$>80$

53.1

16.3

7.73

4.76

3.30

2.42

1.83

1.41

9.05

Profile curv.

$<-0.01$

$-0.01-0.006$

$>0.006$

44.2

11

44.7
0.00

4.82

8.43

28.91

56.62

1.20

50.60

21.68

12.05

6.02

1.20

0.00

2.41

1.20

4.82

53.01

6.02

40.96
1.97

1.79

2.14

1.38

1.00

0.29

0.00

0.61

0.30

0.75

2.57

1.39

0.95

1.32

1.56

1.27

0.36

0.00

1.31

0.85

0.53

1.20

0.54

0.92
0.68

0.58

0.76

0.32

0.00

$-1.23$

0.00

$-0.49$

$-1.29$

0.00

0.94

0.33

$-0.05$

0.28

0.44

0.23

$-1$

0.00

0.27

$-0.15$

$-0.63$

0.18

$-0.61$

$-0.08$
1.00

0.00

0.30

0.48

0.88

1.00

0.91

0.81

1.00

0.59

0.38

0.00

0.00

0.24

0.12

0.29

1.00

0.54

0.61

0.85

1.00

0.81

0.23

0.00

0.84

0.55

0.34

1.00

0.00

0.57 fault map was constructed and divided into seven classes including 0-200, 200-400, 400-600, 6001000 and higher than $1000 \mathrm{~m}$ (figure 3g).
Land use/land cover: It has additionally been demonstrated that land uses assume a vital role in the instability of slope in a few regions (Koukis 

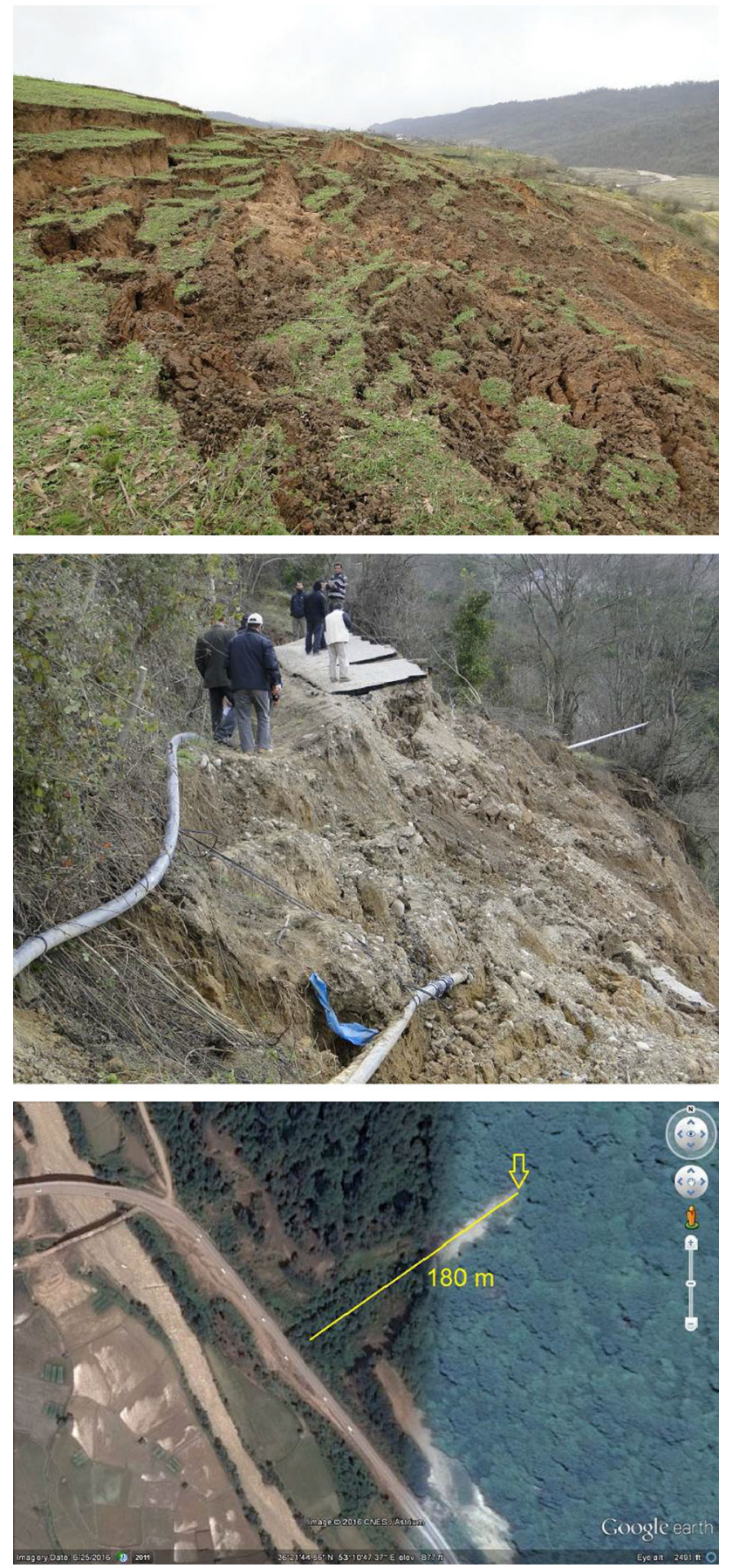

Figure 2. Example of landslides detected by multiple field survey and aerial photographs in the study area.

and Ziourkas 1991; Yalcin 2008). The land that is barren and sparsely vegetated is prone to weathering, erosion and slope instability (Raghuvanshi et al. 2015). Regarding land use and vegetation can be partitioned into 10 units, including dry lands (DF-73.355 $\mathrm{km}^{2}$ ), dense forest lands $\left(\mathrm{F} 1-548.773 \mathrm{~km}^{2}\right)$, semi-dense forest lands (F2-1.5 $\mathrm{km}^{2}$ ), blended forests and orchards (FO$\left.71.766 \mathrm{~km}^{2}\right)$, irrigated agriculture (I1-44.305 km²), blended agriculture and gardens (IO-7.121), trees and garden plants $\left(\mathrm{O}-3.15 \mathrm{~km}^{2}\right)$, garden blend and agriculture (OI-47.906 $\mathrm{km}^{2}$ ) and residential area (U1-1.586 km²) (figure 3n).

Divergence vegetation index: Distinctive densities, classes and distributions of green plants may turn into predominant factors in landslide events (Chou et al. 2009). The diversity of vegetation in the study area was obtained using Landsat images and the use of DVI reiterated the important role played by vegetation in retaining soil moisture and holding soil together because of which they play an imperative role in preventing landslide occurrence. For the present study, the DVI was subdivided by expert opinion based on the density of vegetation in the study area into four classes: $<30$, 30-60, 60-90 and >90 (figure 3c).

\subsubsection{Hydrological factors}

Hydrological factors used in the present study are temperature, rainfall, distance from drainage, SPI and STI (figure 3).

Temperature: Increasing the air temperature can have contrasting consequences on the slope stability. A higher air temperature will expand evapotranspiration on vegetated slopes (Crozier 2010; Senatore et al. 2011), producing positive effects on slope stability, through a reduction of the antecedent water conditions (Comegna et al. 2013). The average annual temperature over a long period of time (30 yr) in the Sari-Kiasar watershed is from 12.41 to $14.48^{\circ} \mathrm{C}$ (Meteorological Organization of Mazandaran Province 2013). For the present study, the temperature was subdivided into five classes: lower than $13.2^{\circ} \mathrm{C}, 13.2-13.6^{\circ} \mathrm{C}, 13.6-14^{\circ} \mathrm{C}, 14$ $14.4^{\circ} \mathrm{C}$ and $14.4-14.8^{\circ} \mathrm{C}$ (figure $3 \mathrm{e}$ ).

Rainfall: The rainfall accelerates landslide occurrences by increasing the weight of soil mass and reducing the strength (Cascini et al. 2011; Lee and Chi 2011) as precipitation is the primary factor to trigger a landslide (Wu et al. 2014). Most landslides have the immediate association with precipitation in the Mazandaran province (Geological Survey of Iran 2013). The mean annual precipitation of $25 \mathrm{yr}$ from 1990 to 2015 for five rain-gauge stations was selected and due to the lower RMSE of the proposed interpolation, the rainfall map was produced by using IDW interpolation method. For the present study, the rainfall was subdivided into six classes includes lower 


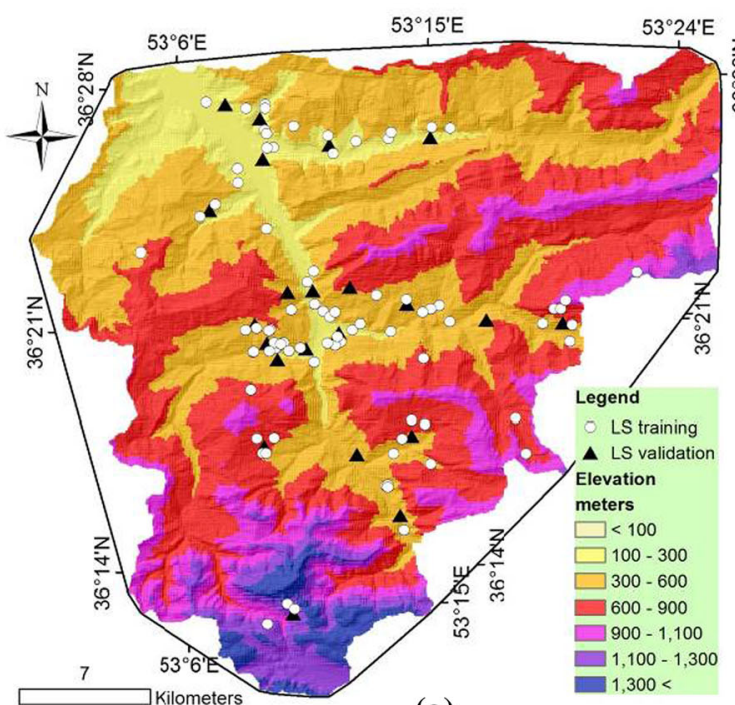

(a)

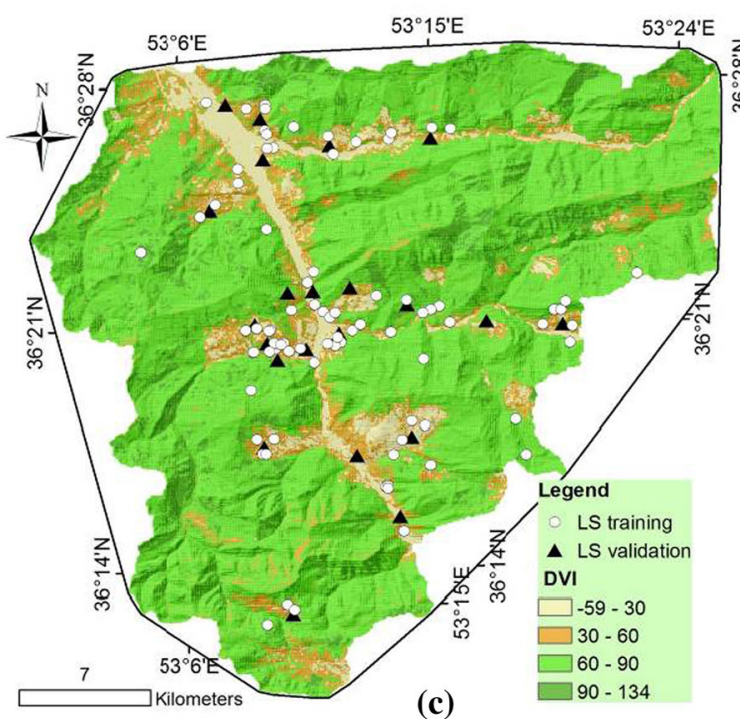

(c)

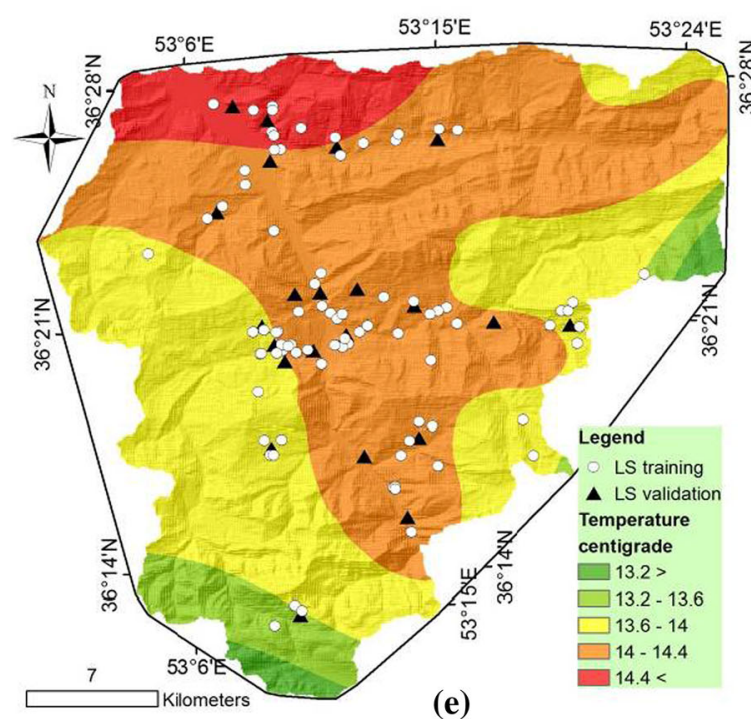

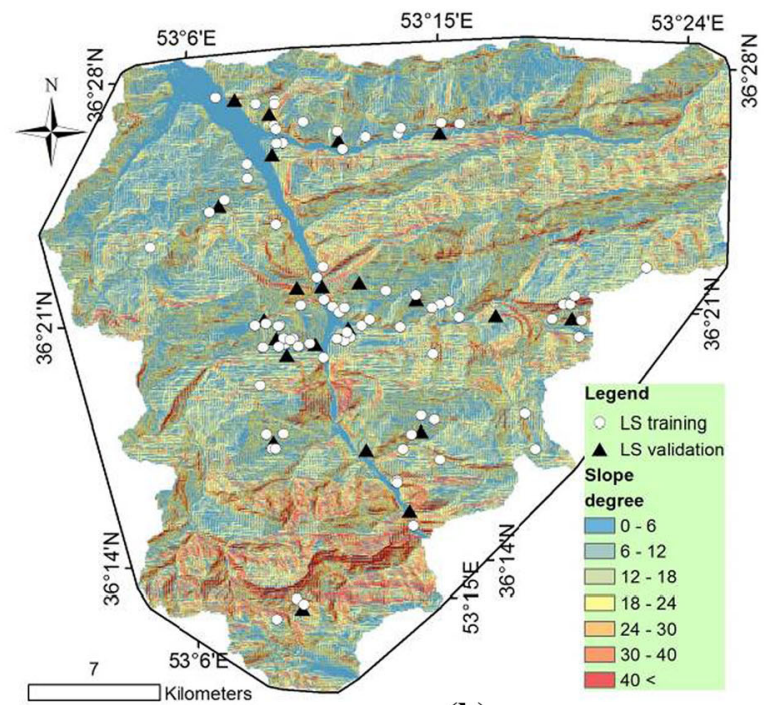

(b)
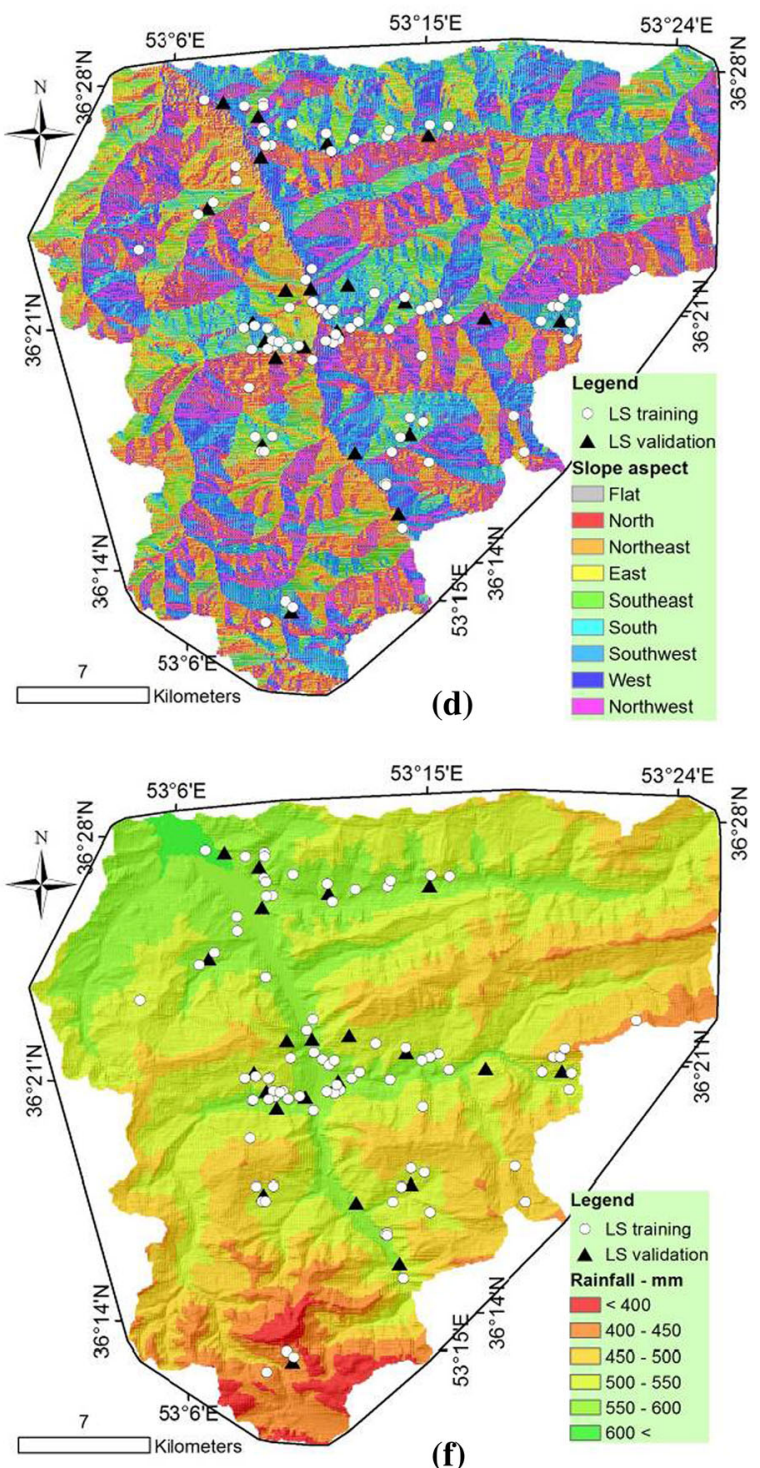

(f)

Figure 3. Landslide contributing-factor layers produced for the study area: (a) elevation, (b) slope angle, (c) DVI, (d) aspect, (e) temperature, (f) rainfall, (g) distance from fault, (h) distance from road, (i) distance from drainage, (j) curvature, (k) profile curvature, (l) plane curvature, (m) settlement density, (n) land use, (o) STI, (p) SPI and (q) lithology. 

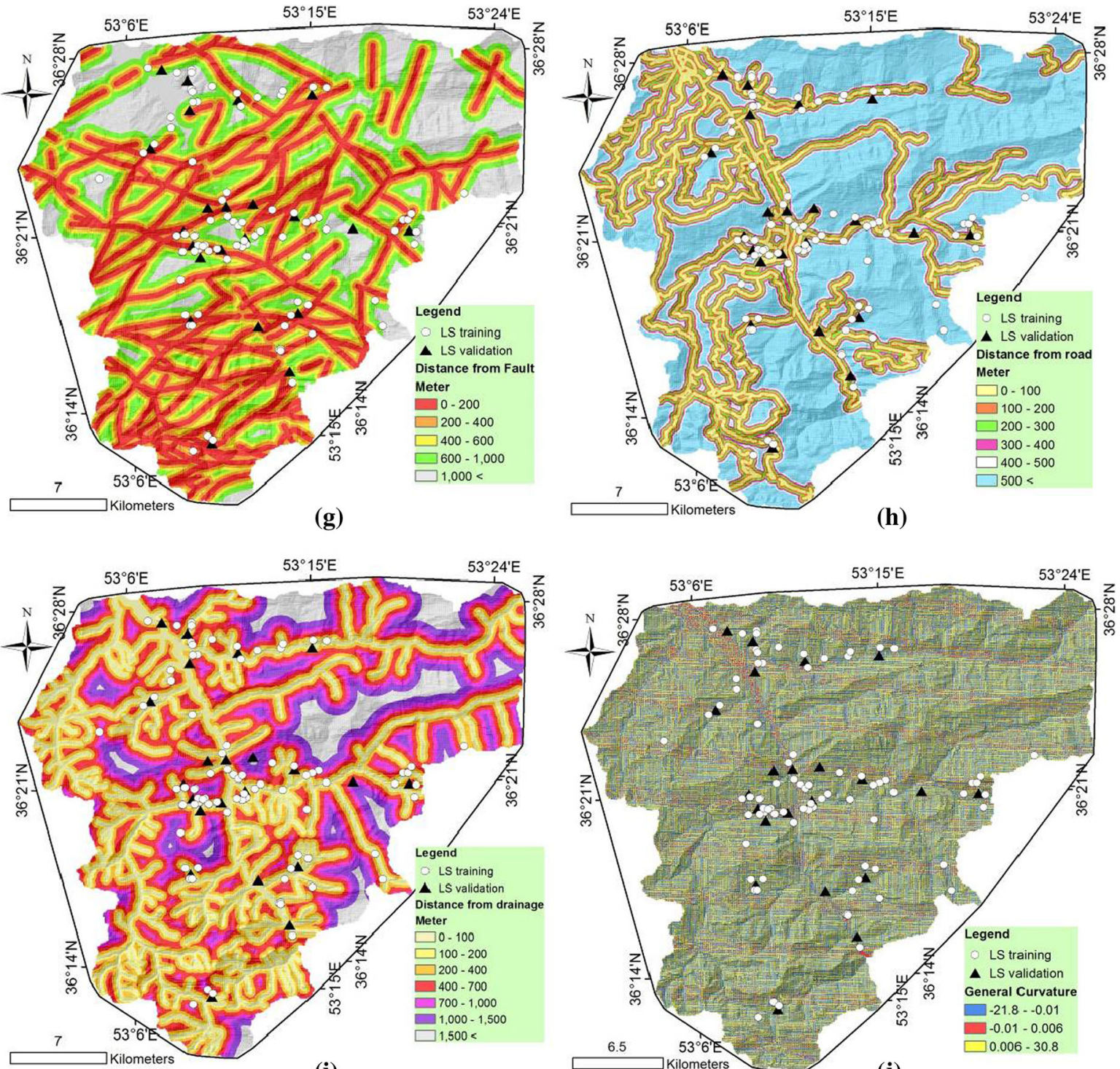

(i)

(j)
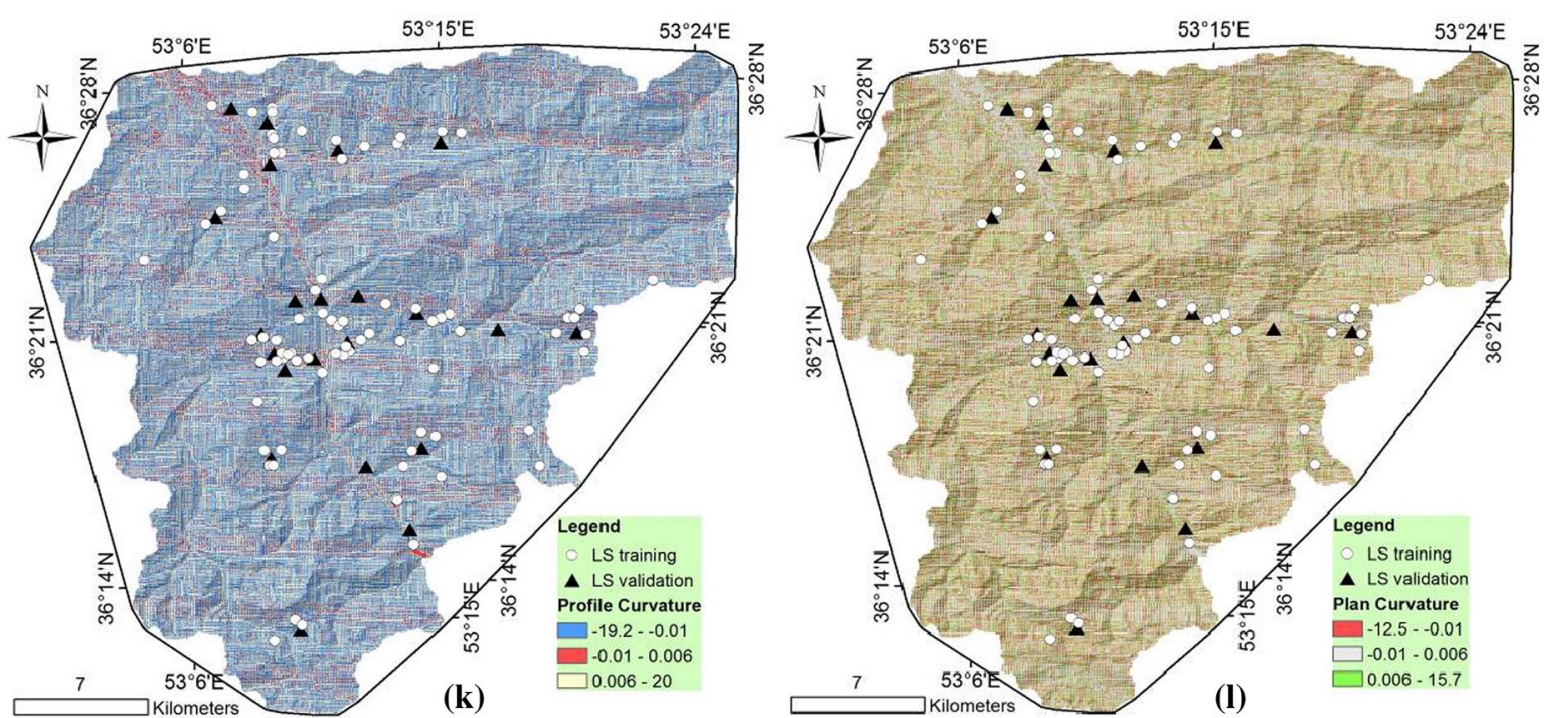

Figure 3. (Continued.) 

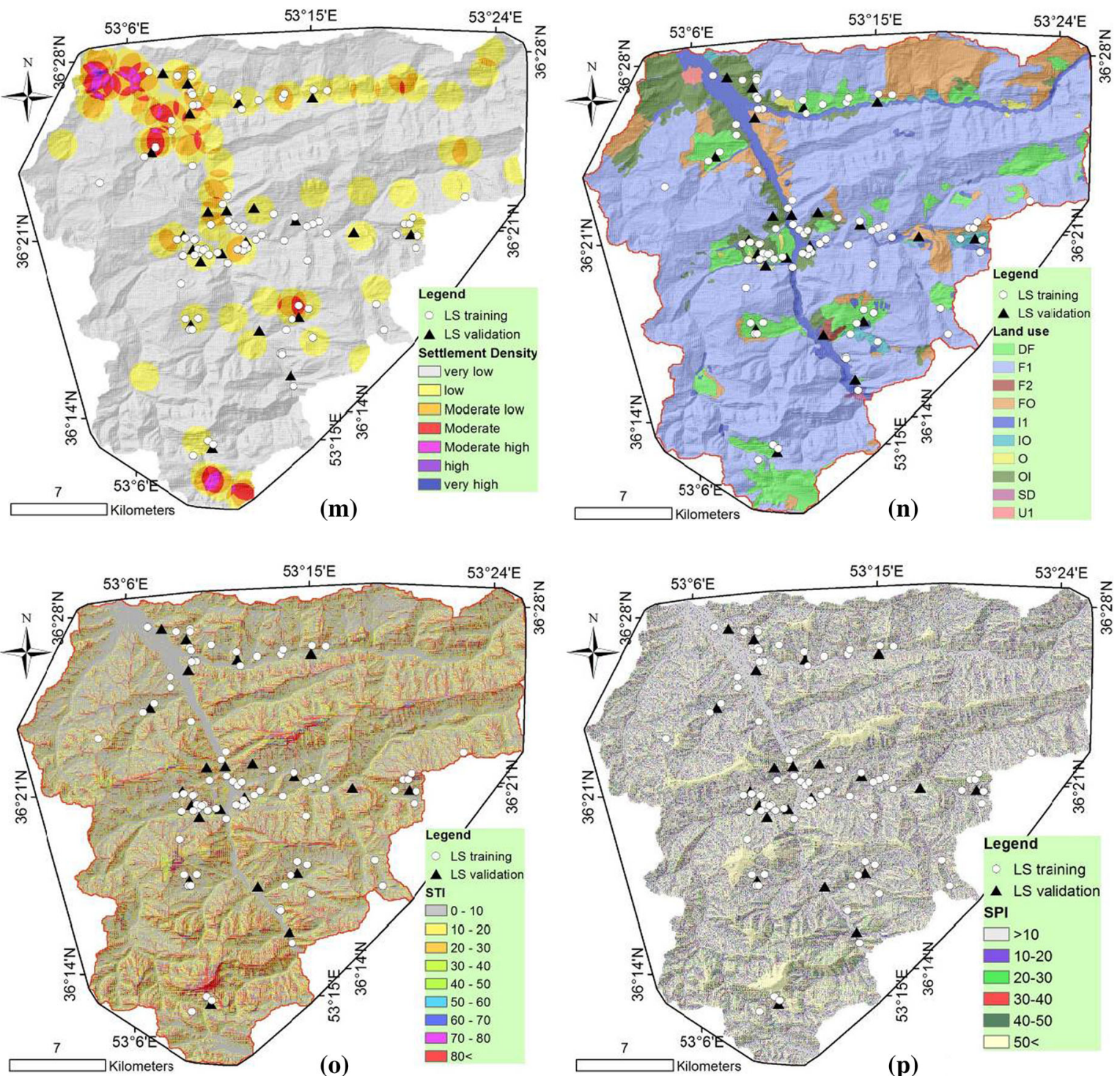

(o)

(p)

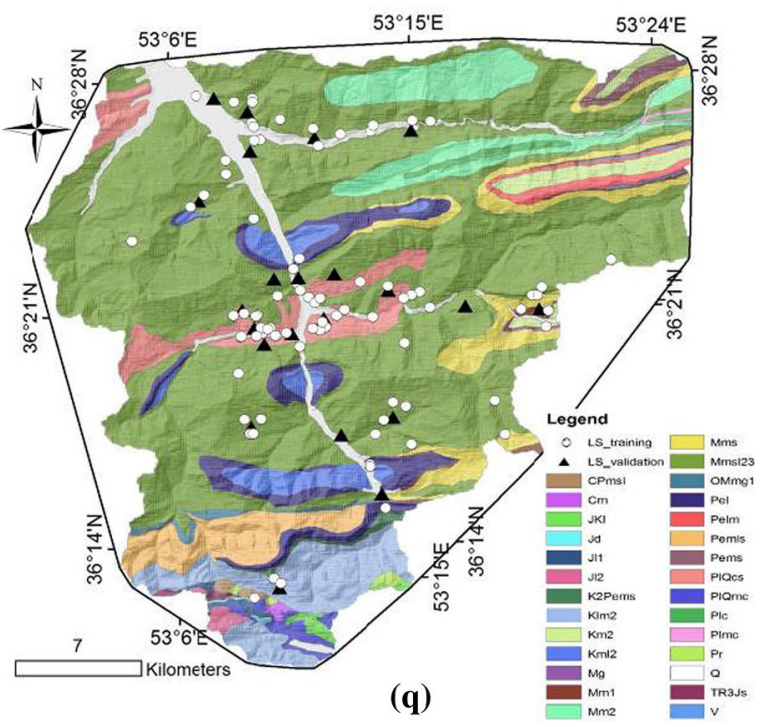

Figure 3. (Continued.) 
than 400, 400-450, 450-500, 500-550, 550-600 and higher than $600 \mathrm{~mm}$ (Eshghabad et al. 2012) (figure 3f).

Distance from drainage: The distance from the drainage can impact on the stability of slopes as water action on the slopes and erosion of the groundmass are more near rivers (Pham et al. 2017) or by saturating the lower part of the material in a hill-slope (Yalcin 2008). The study area was divided into five different buffer ranges including 0-100, 100-200, 200-400, 400-700, 700-1000, 1000-1500 and greater than $1500 \mathrm{~m}$ (Akgun and Turk 2010; Pourghasemi et al. 2013; Hong et al. 2015) (figure 3i).

Stream Power Index: This conditioning factor measures the eroding power of water (Wilson and Gallant 2000; Althuwaynee et al. 2012). A direct relationship of SPI with slope failures shows the more SPI value and the highest landslide occurrence probability (Akgun and Turk 2010; Althuwaynee et al. 2014). This index was derived from DEM using equation (1) (Moore et al. 1991):

$$
\mathrm{SPI}=A \times \tan \beta .
$$

In which $A$ is the slope upstream area to a drainage point $\left(\mathrm{m} / \mathrm{m}^{2}\right)$ and $\beta$ is the slope angle at that point (radian).

As the specific catchment area and gradient increase, the amount of water contributed by upslope areas and the velocity of the water flow increase; hence, the SPI and slope-erosion risk will be increased (Moore et al. 1991). For the present study, the SPI value was subdivided by expert opinion into six classes: 0-10, 10-20, 20-30, 30-40, 40-50 and higher than 50 (Akgun and Turk 2010; Pourghasemi et al. 2012a, b, 2013) (figure 3p).

Sediment Transport Index: The STI is another index frequently used to demonstrate the land flow erosive power (Renard et al. 1997; Pourghasemi et al. 2012a, b). The STI factor in the Universal Soil Loss Equation is a measure of the sediment transport capacity of the overland flow (Moore and Wilson 1992; Pourghasemi et al. 2012a, b, 2013) and is calculated as follows:

$$
\mathrm{STI}=\left(\frac{A}{22.13}\right)^{0.6} \times\left(\frac{\sin (\beta)}{0.0896}\right)^{1.3}
$$

where $A$ is the specific catchment area and $\beta$ is the slope gradient.
This empirical formula resembles the Universal Soil Loss Equation and thus can be used to depict locations of potential erosion risk (Moore and Burch 1986). STI has been derived from DEM using the SAGA 2.2 software. For the present study, the STI value was subdivided into nine classes: 0-10, 10-20, 20-30, 30-40, 40-50, 50-60, 60-70, 70-80 and >80 (Pourghasemi et al. 2012a, b, 2013) (figure 3o).

\subsubsection{Anthropogenic factors}

Some anthropogenic factors that is used in the current study are the distance from road and density of settlement (figure 3 ).

Distance from road: Excavation of roads creates instability in the surrounding rock mass and ground slope (Chang and Wan 2014), thus, the more the distance from the road, the lower landslide occurrences (Yalcin 2008). After producing this layer in ArcGIS10.1 using Multi-ring buffer command, it is divided into 0-100, 100-200, 200300, 300-400, 400-500 and >500 $\mathrm{m}$ (Pourghasemi et al. 2013) (figure 3h).

Density of settlement: Human movement, such as road excavation and cutting a slope to build a house, is the primary component influencing the landslide occurrences ( $\mathrm{Wu}$ et al. 2014). It is expected that if the alternate conditions are provided for the event of landslides, construction factor will be enhanced susceptibility to landslides. For the present study, the density of settlement was subdivided into seven classes including very low, low, moderately low, moderate, moderately high, high and very high (figure $3 \mathrm{~m}$ ).

\section{Methodology}

In the present study, FR, FG and LIMs were applied into the landslide susceptibility mapping at the Sari-Kiasar watershed. The main assumption of the present study is to model the possible occurrence of a landslide in the future using the same conditions of a past landslide (Lee and Pradhan 2006). This approach provides the steps in the flowchart given in figure 4 .

\subsection{Frequency ratio}

FR model was applied in order to evaluate the landslide susceptibility of the case study based on the observed spatial relationship between landslide 


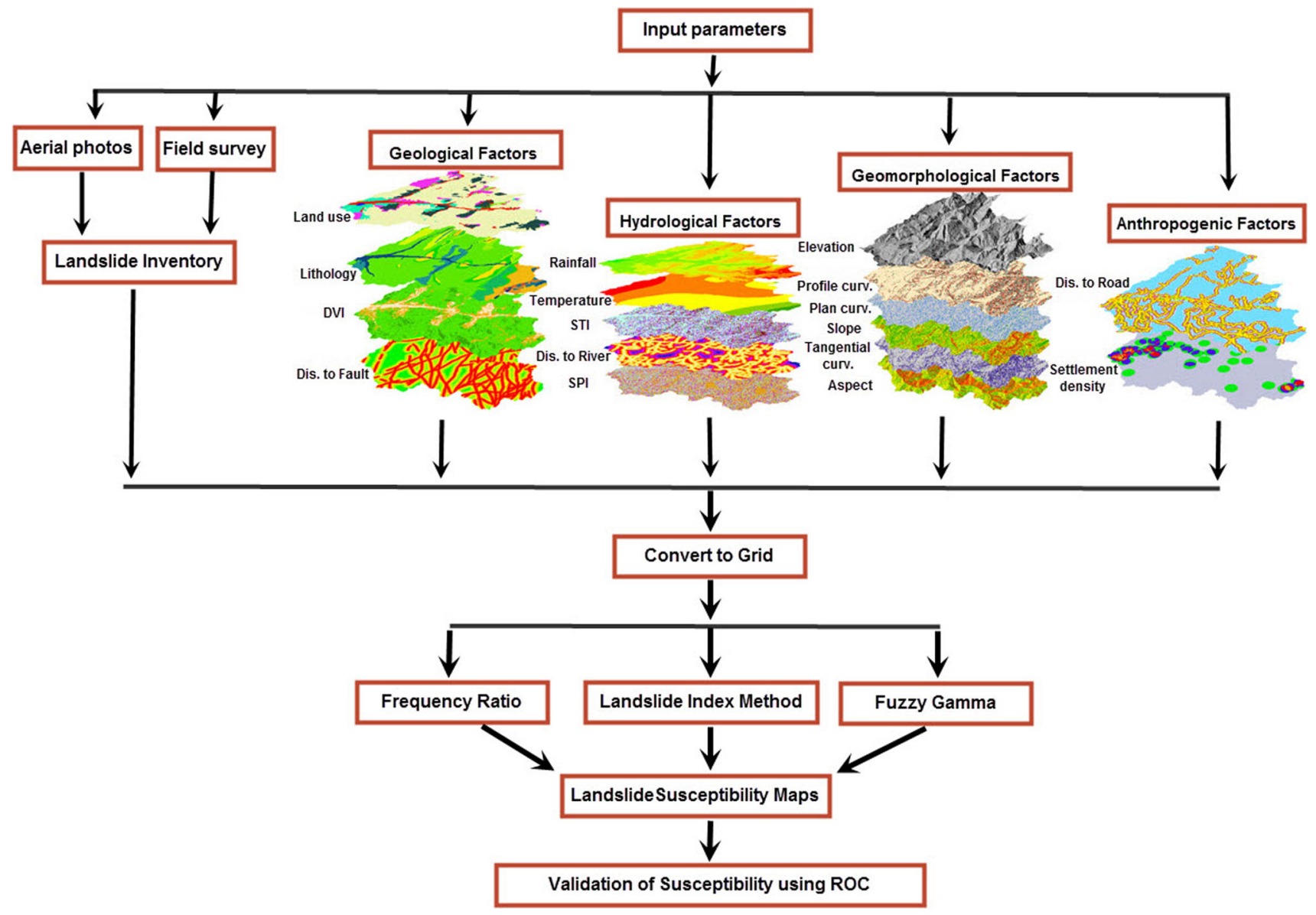

Figure 4. Flowchart of the proposed approach.

occurrences and conditioning factors. The FR is the ratio of the probability of the presence to the absence of landslide occurrence (Lee and Pradhan 2007; Yilmaz 2009). The advantages of this model are that it can be simply implemented and its result is completely easy to comprehend (Yalcin et al. 2011; Ozdemir and Altural 2013). FR is expressed in equation (3), and landslide susceptibility index (LSI) was calculated by sum of each factor's ratio value using the following equation (equation 4) (Lee and Sambath 2006; Lee and Pradhan 2007; Park et al. 2013; Hong et al. 2015; Khosravi et al. 2016a):

$$
\begin{aligned}
\mathrm{FR}= & {\left[N_{\text {pix }}\left(S X_{i}\right) / \sum_{i=1}^{m} S X_{i}\right] } \\
& /\left[N_{\text {pix }}\left(X_{j}\right) \text { Big/ } \sum_{j=1}^{n} N_{\text {pix }}\left(X_{j}\right)\right], \\
\mathrm{LSI}= & \sum_{j=1}^{n} \mathrm{FR}
\end{aligned}
$$

where $N_{\text {pix }}\left(S X_{i}\right)$ is the number of pixels with landslides within class $i$ of factor variable $X$, $N_{\text {pix }}\left(X_{j}\right)$ is the number of pixels within factor variable $X_{j}, m$ is the number of classes in the parameter variable $X_{i}$ and $n$ is the number of factors that were selected for modelling in the study area (Regmi et al. 2013; Jaafari et al. 2014). In FR, the ratio is that of the area where the landslide occurred to the total area. Thus, a value of 1 is an average value or threshold (Akgun and Bulut 2007). A value of lower than 1 shows a lower correlation, whereas values higher than 1 mean a higher correlation (Akgun and Bulut 2007; Park et al. 2013).

\subsection{Ensemble of $F G$ method with FR}

Fuzzy logic is an attractive method as it is straightforward to understand and implement (Zadeh 1965; An et al. 1991). It can be used with data from any measurement scale and the weighting of evidence can be controlled by the expert. The fuzzy logic method allows for more flexible 
combinations of weighted maps and can be readily implemented with a GIS modelling language (Ilanloo 2011). The idea of fuzzy logic (Zadeh 1965) is to consider the spatial objects on a map as members of a set. In classical set theory, an object is a member of a set if it has a membership value of 1 , or not a member if it has the membership value of 0 . In this study, fuzzy membership values have been assigned based on FR model (table 3). Each factor is standardised between 1 and 0 to produce fuzzy membership values. A variety of operators can be employed to combine the membership values when two or more maps with fuzzy membership functions for the same set are available, including fuzzy AND, fuzzy OR, fuzzy algebraic product, fuzzy algebraic sum and FG operator (An et al. 1991). In the current study, FG operator was applied for combining the fuzzy membership functions as its prediction capability was proved in the landslide susceptibility mapping (Ramesh et al. 2016).

For fuzzy analysis, at first, the weights of FR were standardised (Lefteri and Robert 1997) and then have been used as an input data for fuzzy analysis. Given at least two maps with fuzzy membership functions, $\mu_{A}(x), \mu_{B}(x), \ldots, \mu_{N}(x)$, for the similar set, a variety of operators, e.g., FG can be utilised to consolidate the membership values as follows (equation 5) (An et al. 1991; Chung and Fabbri 2001; Eastman 2003):

$$
\begin{aligned}
& \text { Fuzzy }[\text { GAMMA }]: \mu_{\gamma}(x) \\
& \quad=\left[\mu_{\text {SUM }}(x)^{\gamma}\right] \times\left[\mu_{\text {PROdUCT }}(x)\right]^{1-\gamma} .
\end{aligned}
$$

Gamma fuzzy operator is the general method of augmentation and expansion operators. This operator, by choice of the gamma value, expanding and diminishing parameters joined in the meantime and accomplishing the values in the output. Subsequent from the flexible compatibility, there are rising or falling propensities of fuzzy multiplication and $\gamma$ is variable between zero and one. In this method for the fuzzy 'GAMMA' operator, the $\gamma$ value of $0.9,0.95$ and 0.975 was assigned for producing a landslide susceptibility index (table 3).

\subsection{Landslide index method}

The LIM method has been introduced by Van Westen (1997) for landslide susceptibility mapping. This method requires important selected parameters for classification. Therefore, it can imply their classification into relevant classes, and finally to overlaying the landslide inventory map with each conditioning factor (Van Westen 1997; Ruff and Czurda 2008). Weight values for each class of each factor are calculated as the natural logarithm of landslide density of the class divided by the total landslide density of the study area (Van Westen 1997; Ozdemir and Turoglu 2007; Safari and Moghimi 2009; Yalcin et al. 2011; Nezhadali et al. 2013; Santos 2013). In this study, the $W i$ values for each class of each conditioning factor map were obtained quantitatively using the following formula (Van Westen 1997; Ozdemir and Turoglu 2007):

$$
\begin{aligned}
\ln W i & =\ln \left(\frac{\text { Densclas }}{\text { Densmap }}\right) \\
& =\ln \left(\frac{N \operatorname{pix}(\mathrm{Si}) / N \operatorname{pix}(\mathrm{Ni})}{\sum N \operatorname{pix}(\mathrm{Si}) / \sum N \operatorname{pix}(\mathrm{Ni})}\right),
\end{aligned}
$$

where $W i$ (the weight given to a certain conditioning factor class, e.g., a rock type, or a slope class), Densclas is the landslide density within the conditioning factor class, Densmap is the landslide density within entire map, $N$ pix $(\mathrm{Si})$ is number of pixels, which contain landslides, in a certain conditioning factor class, $N \operatorname{pix}(\mathrm{Ni})$ is the total number of pixels in a certain conditioning factor class.

\subsection{Model validation}

In this study, $75 \%$ of landslide locations were used for model building and the remaining $25 \%$ of landslide locations or testing datasets, which were not used in the training phase, were used to evaluate the prediction capability of the models. The receiver operating curve (ROC) is one of the most popular techniques to evaluate the model's efficiency and area under the ROC curves (AUC) can calculate to model accuracy quantitatively (Metz 1978; Morrison 2005). In fact, the AUC represents the predicted value of the system through the description of its ability to correctly estimate the events that have occurred (landslides) and the events that have not occurred (no landslides). The ideal model has the most area under the curve and AUC values vary from 0.5 to 1 (Chung and Fabbri 2003; Lee and Dan 2005; Pradhan and Lee 2010). The model with higher AUC is considered to have the better performance and its classifications are as follows (0.90-1.0 excellent, 0.80-0.90 good, $0.70-0.80$ fair, $0.60-0.70$ poor and $0.50-0.60$ 
indicates failure of the model) (Abul Hasanat et al. 2010).

\section{Results and discussion}

This study has analysed the relationship between 17 conditioning factors and landslide occurrence and the FR ratio, fuzzy membership and $W i$ values were calculated. The weight of each class in all 17 factors in landslides is shown in table 3.

\subsection{Frequency ratio}

The FR method was produced using the weights of each class of each conditioning factor. For elevation, the high FR was observed in 100-300 m class $(\mathrm{FR}=2.34)$ (table 3$)$. The possible causes for the concentration of the landslide occurrences in this class can be correlated with the residential area, road and mine excavation, and areas with scattered forest at this class. For elevation higher than $300 \mathrm{~m}$ due to the dense vegetation and far from roads and residential areas, landslide occurrences have been reduced. In the case of slope angle, high FR belongs to $18-24^{\circ}$ class $(\mathrm{FR}=1.13)$, it showed that by increasing the slope angle to $24^{\circ}$, the FR of landslide occurrences generally increases. At slope higher than $24^{\circ}$ due to less water infiltration, landslides occurrence reduced. The results of the aspect revealed that the concentration of landslides in the slope, facing towards the south and southwest directions may be related to the higher slope in the south and southwest direction areas. The result of FR for plane curvature showed a similar landslide distribution both on concave and convex slopes. The landslide index showed a value of $20.48 \%$ for both the concave and convex slopes. The relationship between landslides and profile and general curvature maps indicated a similar landslide distribution both on concave and convex slopes as well. In the profile curvature and general curvature, the landslide index depicted a value of $53.01 \%$ and $42.17 \%$ for concave slopes and $40.96 \%$ and $50.6 \%$ for convex slopes, respectively. In particular, it was observed that a complex and flow-type landslide falls on concave slopes in the profile curvature and on convex slopes in the general curvature as well.

In the case of lithology, 4 units had the highest FR of occurrence of landslides in the case study including: Q (alluvium), CPmsl (variegated red-brown-grey silty marl, calcareous sandstone, shales, thin-medium bedded limestone, marly limestone), Mm1 (homogeneous ochre coloured marls), PlQcs (conglomerate, sandstone, siltstone, silty marl). Less resistance lithology units such as alluvium, marl, marlstones, sandstones and conglomerate are very susceptible to landslides.

In LULC, the high frequency of landslides was observed in the garden blend with agriculture (OI) class that prone to landslide occurrences. The main reason is that the other factor controls the landslide occurrences in the study area which is more stronger than LULC, such as slope angle (18$\left.24^{\circ}\right)$, elevation $(100-300 \mathrm{~m})$, moderate vegetation cover and lithology (Q, CPmsl, Mm1 and PlQcs) at these classes. The frequency of STI and SPI factor classes shows that these factors have a positive impact on the occurrence of landslides as, the more the SPI and STI, the higher is the probability of landslide occurrences. There is not much of a difference between the maximum and minimum temperature in this study area; therefore, temperature as a factor has not been included in preparing landslide susceptibility mapping. Landslide occurrences were observed when rainfall is in the range of $550-600 \mathrm{~mm}(\mathrm{FR}=2.57)$. The result of the FR method showed that more rainfall is associated with higher landslide occurrence. According to the vegetation factor in the present study, the DVI showed that with increasing dense vegetation, the frequency of landslides generally decreases. As a general rule, the greater the distance from roads, rivers and faults, the less the landslide FR. In the study area, the distance from the road and the river confirms this issue, but there is no significant relationship between the frequency of landslides and classes of the distance from the fault factor. Most landslides occur near the road $(0-300 \mathrm{~m})$ and river $(0-100 \mathrm{~m})$. Three classes of very low, low and moderate to low cover $96.47 \%$ of the total area and in this portion $95.37 \%$ of landslide occurrence and high and very high classes cover $3.53 \%$ of the total areas. The high frequency of landslides in this region occurs near the settlement and the more the settlement density, the higher landslide occurrences probability (figure 5a).

\subsection{FG method}

Fuzzy membership values were calculated according to the pixel values tabulated in table 3 . In the case of fuzzy 'GAMMA' operator, the three common $\gamma$ values of $0.9,0.95$ and 0.975 were 

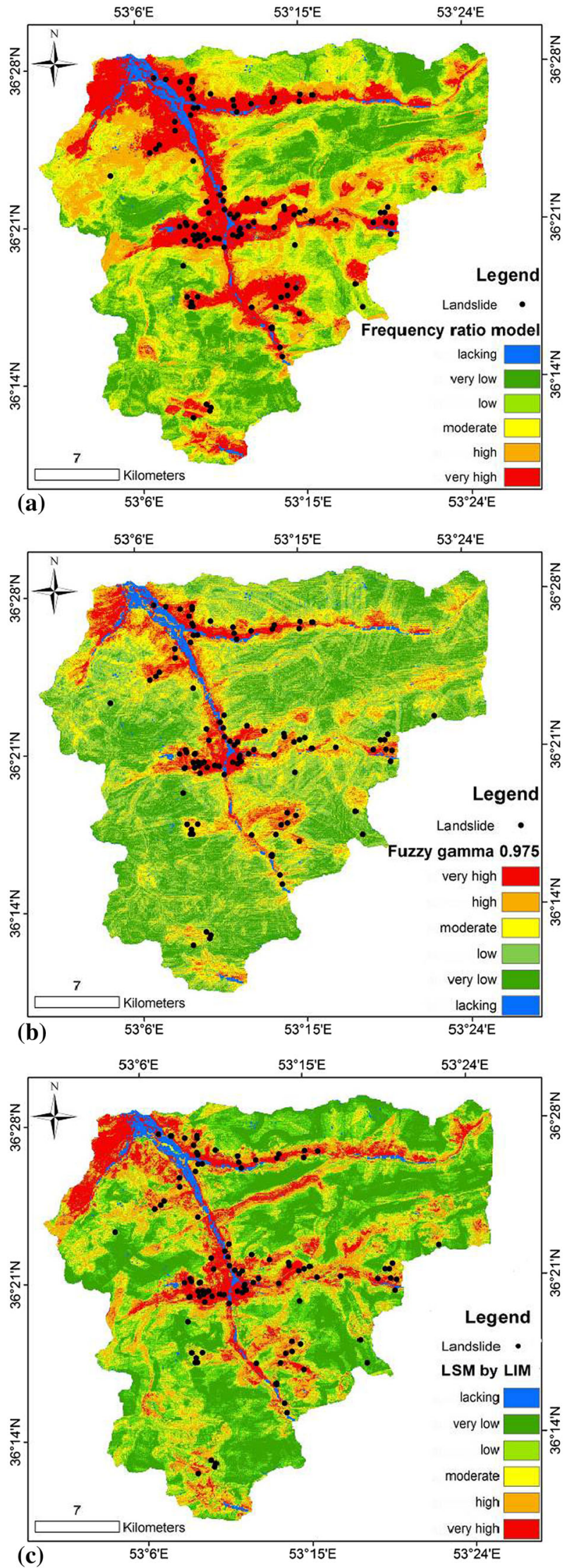

Figure 5. The landslide susceptibility map of the study area of FR, FG operator $(\gamma=0.975)$ and LIM models. assigned for producing a landslide susceptibility index. At first, the weights from FR in each class of factor were standardised by using the fuzzy membership tool and then have been used as an input data to fuzzy analysis. In this study, fuzzy membership values have been assigned based on the FR model (table 3). In each factor, higher to lower FR was standardised between 1 and 0 to produce the fuzzy membership values. For instance, in elevation factor the FRs for seven classes are 0, 2.34, $1.53,0.38,0,0.76$ and 0 , respectively, and are given in table 3 and in the fuzzy membership column they are $0,1,0.65,0.16,0,0.32$ and 0 , respectively. Among the $\gamma$ values, the $\gamma$ value of 0.975 was shown to be the best result for producing a landslide susceptibility index. The maps resulting from the FG model were shown in figure 5(b).

\subsection{Landslide index method}

$W i$ values were calculated according to the pixel values tabulated in table 3 . Comparing the result of this model with the FR method showed a high degree of correlation; in general, the class with the highest weight and lowest weight was similar in both models with little difference. In the case of elevation, landslide mostly occurred in the elevation range of $100-300 \mathrm{~m}(W i=0.85)$. For the slope angles $18-24^{\circ}$, the $W i$ value was 0.12 , which illustrated that the more the slope angle, the higher the susceptibility to landslide occurrence. Also, the impact of the aspect was evaluated as a contributor to landslide occurrence. For the slope aspect, $W i$ value was highest (0.5) for the class of south. The highest $W i$ values for rainfall classes belonged to the area of $550-600 \mathrm{~mm}$ precipitation with a ratio of 0.94 . For SPI and STI, the $W i$ values were highest 0.8 and 0.44 for the classes of 40-50 and 20-30, respectively. For LULC, the highest $W i$ value of 1.44 was achieved for the garden blend and agriculture (OI) class which amplified the landslide occurrences. The most effective class of distance from the river was $100 \mathrm{~m}$ with a $W i$ value of 0.63 . The geological layers revealed that the most slide events in the study area occurred in the Q, CPmsl, Mm1 and PlQcs units with Wi values of $1.26,1.9,1.32$ and 1.57, respectively. In the case of distance from roads, the higher $W i$ values $0.68,0.58$ and 0.76 were found to be between 0 and 100, 100 and 200 and 200 and $300 \mathrm{~m}$, respectively. For DVI, the higher $W i$ values 1.15 and 1.27 were found to be between 0 and 30 and 30 and 60 classes, respectively, and the result shows that by 

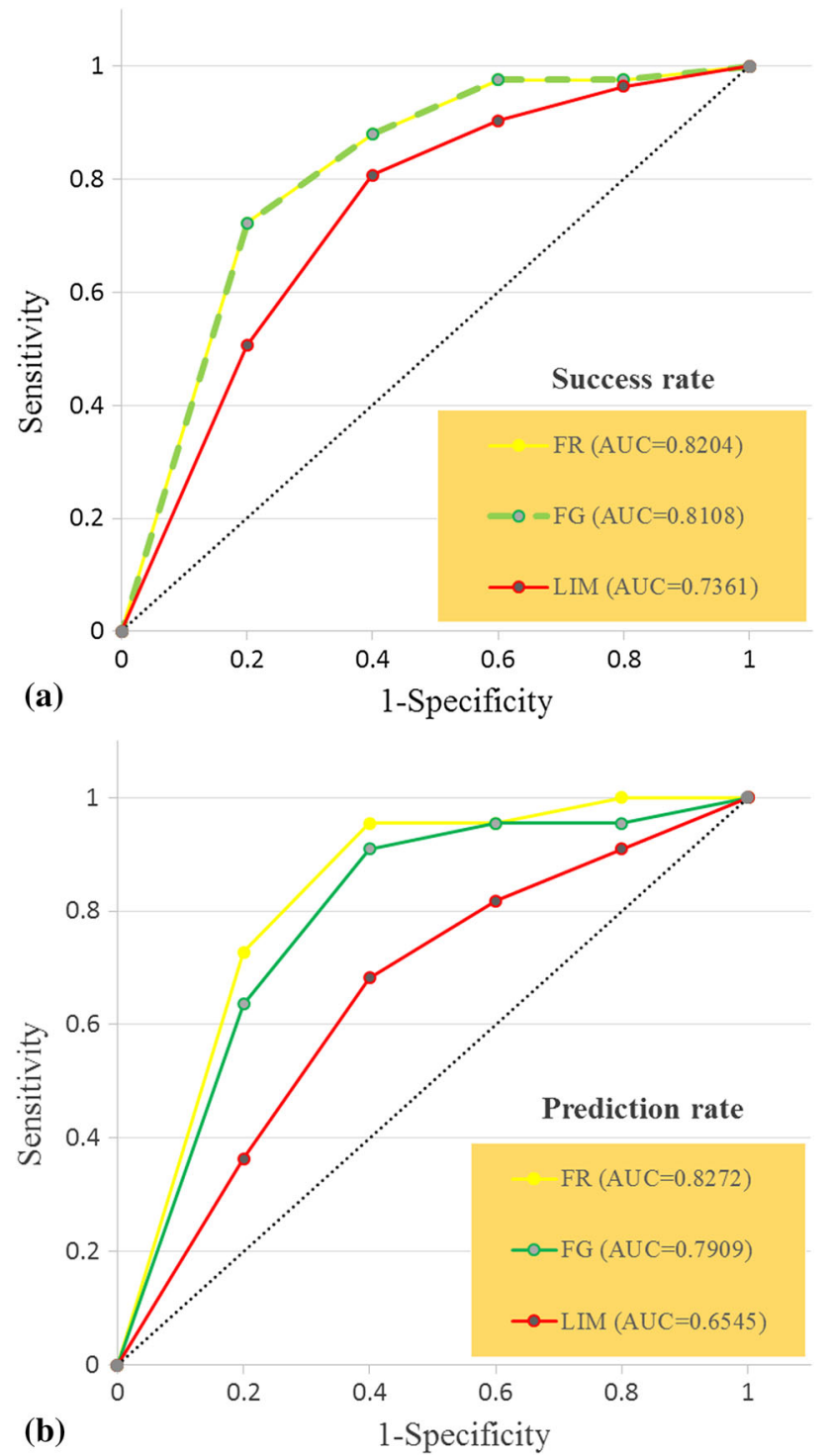

Figure 6. The success and prediction curve of FR, FG operator $(\gamma=0.975)$ and LIM by ROC curve.

increasing the dense vegetation, the frequency of landslides generally decreases. Also, results demonstrated that there is a negative correlation between landslide occurrence and temperature and distance from the fault, thus, these conditioning factors were omitted. The final values of pixels change between 0 (no susceptibility) and 4.17 (high susceptibility) (figure 5c).

In particular, the coefficient that belongs to the conditioning factors 'precipitation, slope and vegetation' has a stronger effect on the development of landslides than any other conditioning factors in the region of the Sari-Kiasar watershed.

The classification of the final map into different susceptibility classes is very difficult. The landslide susceptibility map was obtained and the
Table 4. Results of validation of output maps by of FR, FG operator $(\gamma=0.975)$ and LIM models.

\begin{tabular}{lcc}
\hline & \multicolumn{2}{c}{ AUC (\%) } \\
\cline { 2 - 3 } Model & Success rate & Prediction rate \\
\hline FR & 82.04 & 82.72 \\
FG 0.9 & 74.71 & 74.45 \\
FG 0.95 & 77.69 & 76.87 \\
FG 0.975 & 81.08 & 79.09 \\
LIM & 71.63 & 65.45 \\
\hline
\end{tabular}

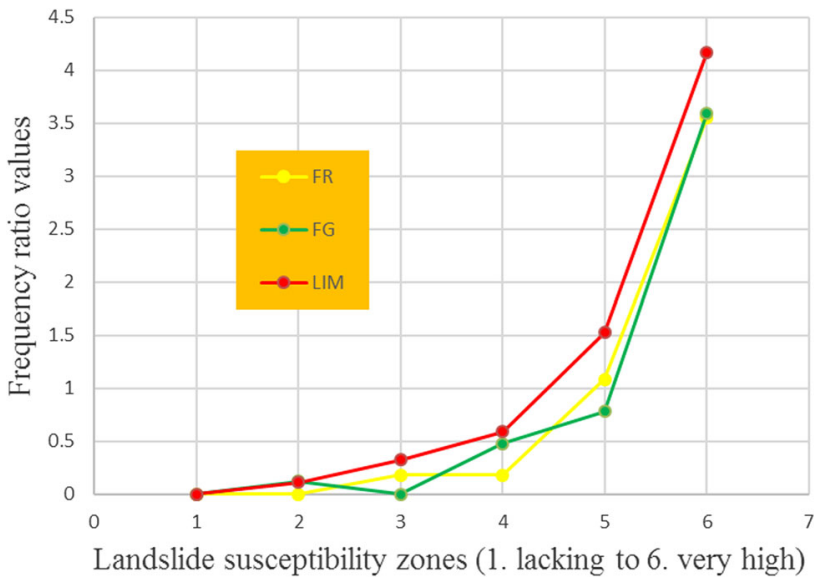

Figure 7. FR plots of six landslide susceptibility zones of the three models.

study area was divided into six classes of landslide susceptibility: lacking, very low, low, medium, high and very high (figure 6).

\subsection{Validation and comparison of LSM}

In this study, the success and prediction of ROC curve and AUC have been used for the model validation process. The success rate has been constructed using the training dataset $(75 \%)$ and it cannot be used to show a model prediction capability (Khosravi et al. 2016a, b). Success rate results of the models are shown in figure 6(a), which indicate a higher prediction capability for the FR model $(82.04 \%)$ followed by FG $0.975(81.08 \%)$ and LIM model $(73.61 \%)$. The prediction rate has been constructed using the testing dataset (25\%). The AUC values for prediction rate curves are also shown in figure 6(b). The AUC of the models for the testing phase is $82.72 \%, 79.09 \%$ and $65.45 \%$ for FR, FG (0.975) and LIM methods, respectively (figure 6b and table 4). The results also showed that the FR model has higher prediction accuracy than that 
of Landslide index and FG model to landslide prediction in the Sari-Kiasar watershed.

For further comparison of the models, a frequency curve (percentage of landslide occurred in each zone divided by the zone area percentage) of the three models was plotted in figure 7 . Theoretically, the frequency of the occurrence of landslides of different zones should increase from lacking and very low to very high susceptible zone, where the rate of increase is much higher for the classes of high and very high susceptible zones (Pradhan and Lee 2010). Based on this point, figure 7 shows that the FR, FG and LIM methods will differentiate the high and very high classes from the other classes.

\section{Conclusion}

The main aim of the current research is the prediction capability of three models, namely FR, FG and LIM for determination of the landslideprone areas in Sari-Kiasar watershed. In the first step, 105 landslide locations have been recognised and divided into two categories randomly of 78 locations for modelling (75\%) and 27 locations for model validation (25\%). In the next step, 17 landslide conditioning factors including geological factors (land use, DVI, lithology and distance from faults), geomorphological (elevation, slope aspect, slope angle, tangential curvature, profile curvature and plane curvature), hydrological (distance from drainage, rainfall, SPI, STI and temperature) and anthropogenic factors (distance from road, density of settlement) were prepared and mapped to the detection of spatial relationship between landslide occurrence and conditioning factors in the study area. A reliable and accurate susceptibility map depends on the inclusion and proper determination of the role of these conditioning factors. Of the 17 conditioning factors, the temperature has been omitted because there is no significant relationship between landslide occurrences with this factor. The most important conditioning factors are 'precipitation, slope and vegetation' which have a stronger effect on the landslide occurrences in the region of the Sari-Kiasar watershed. LSM were constructed by using FR, FG and LIM on the training dataset. Finally, the prediction capability of the performed model has been evaluated on the testing dataset by using the area under the ROC curve. The results show that the AUC for success rate of FR, FG 0.975 and LIM models were $82.04 \%, 81.08 \%$ and $73.61 \%$ and for prediction rate were $82.72 \%, 79.09 \%$ and $65.45 \%$, respectively. The results show that the FR model has higher prediction accuracy than that of LIM and FG models. The LSM produced for the Sari-Kiasar watershed allow the identification of the most problematic areas and can predict future landslide locations where events have not been occurred previously; however, the high and very high susceptible zones should be examined in a larger scale study. The result of the current study has shown a great deal of importance for land use planning and watershed management.

\section{Acknowledgements}

The authors are thankful to the Mazandaran Regional Water Authority and the Natural Resources Bureau of Mazandaran for providing data to accomplish this study.

\section{References}

Abul Hasanat M, Ramachandram D and Mandava R 2010 Bayesian belief network learning algorithms for modeling contextual relationships in natural imagery: A comparative study; Artif. Intell. Rev. 34 291-308.

Ahmed S 2009 Slope stability analysis using GIS and numerical modeling techniques (unpublished M.Sc. thesis), Vrije Universiteit, Brussel.

Akgun A and Bulut F 2007 GIS-based landslide susceptibility for Arsin-Yomra (Trabzon, North Turkey) region; Environ. Geol. 51(8) 1377-1387.

Akgun A and Turk N 2010 Landslide susceptibility mapping for Ayvalik (Western Turkey) and its vicinity by multicriteria decision analysis; Environ. Earth Sci. 61(3) 595-611.

Althuwaynee O F, Pradhan B and Lee S 2012 Application of an evidential belief function model in landslide susceptibility mapping; Comput. Geosci. 44 120-135.

Althuwaynee O F, Pradhan B, Park H J and Lee J H 2014 A novel ensemble bivariate statistical evidential belief function with knowledge-based analytical hierarchy process and multivariate statistical logistic regression for landslide susceptibility mapping; Catena 114 21-36.

An P, Moon W and Rencz A 1991 Application of fuzzy set theory for integration of geological, geophysical and remote sensing data; Can. J. Explor. Geophys. 27 1-11.

Ayalew L, Yamagishi H and Ugawa N 2004 Landslide susceptibility mapping using GIS-based weighted linear combination, the case in Tsugawa area of Agano River, Niigata Prefecture, Japan; Landslides 1 73-81.

Ayalew L, Yamagishi H, Marui H and Kanno T 2005 Landslides in Sado Island of Japan: Part II. GIS - based susceptibility mapping with comparisons of results from two methods and verifications; Eng. Geol. 81 432-445.

Barrile V, Cirianni F, Leonardi G and Palamara R 2016 A fuzzy-based methodology for Landslide Susceptibility Mapping; Procedia Soc. Behav. Sci. 223 896-902. 
Caniani D, Pascale S, Sdao F and Sole A 2008 Neural networks and landslide susceptibility: A case study of the urban area of Potenza; Nat. Hazards 45 55-72.

Carson M A and Kirkby M J 1972 Hillslope form and process; Cambridge University Press, New York, Vol. 178(4065), pp. 1083-1084, https://doi.org/10.1126/science.178.4065. 1083-a.

Cascini L, Cuomo S and Sala M D 2011 Spatial and temporal occurrence of rainfall-induced shallow landslides of flow type: A case of Sarno-Quindici, Italy; Geomorphology 126(1-2) 148-158, https://doi.org/10.1016/ j.geomorph.2010.10.038.

Cevik E and Topal T 2003 GIS-based landslide susceptibility mapping for a problematic segment of the natural gas pipeline, Hendek (Turkey); Environ. Geol. 44949 962.

Chang S H and Wan S 2014 Discrete rough set analysis of two different soil behavior induced landslides in National Shei-Pa Park, Taiwan; Geosci. Front., https://doi.org/10. 1016/j.gsf.2013.12.010.

Chou W C, Lin W T and Lin C Y 2009 Vegetation recovery patterns assessment at landslides caused by catastrophic earthquake: A case study in central Taiwan; Environ. Monit. Assess. 152(1-4) 245-257.

Chung C and Fabbri A 2001 Prediction models for landslide hazard zonation using a fuzzy set approach; Geomorphology and Environmental Impact Assessment Balkema, Lisse, The Netherlands, pp. 31-47.

Chung C J F and Fabbri A G 2003 Validation of spatial prediction models for landslide hazard mapping; Nat. Hazards 30(3) 451-472.

Comegna L, Picarelli L, Bucchignani E and Mercogliano P 2013 Potential effects of incoming climate changes on the behavior of slow active landslides in clay; Landslides $\mathbf{1 0}(\mathbf{4})$ 373-391, https://doi.org/10.1007/s10346-012-0339-3.

Conforti M, Pascale S, Robustelli G and Sdao F 2013 Evaluation of prediction capability of the artificial neural networks for mapping landslide susceptibility in the Turbolo river catchment (northern Calabria, Italy); Catena, https://doi.org/10.1016/j.catena.2013.08.006.

Crosby D A 2006 The effect of DEM resolution on the computation of hydrologically significant topographic attributes; M. S. Thesis Arts, Department of geography, College of Arts and Sciences, University of South Florida, 135p.

Crozier M J 2010 Deciphering the effect of climate change on landslide activity: A review; Geomorphology 124 260-267.

Eastman J R 2003 IDRISI Kilimanjaro: Guide to GIS and image processing; Clark Labs, Clark University, Worcester, $328 \mathrm{p}$.

Eshghabad S M, Solaimani K and Omidvar E 2012 Landslide susceptibility mapping using multiple regression and GIS tools in Tajan Basin, north of Iran; Environ. Nat. Res. Res. 2(3).

Evans I S 1979 An integrated system of terrain analysis and Slope mapping; Final Report on Grant DA-ERO-591-73G0040, University of Durham, Durham, UK.

Farrokhnia A, Pirasteh S, Biswajeet P, Pourkermani M and Arian M 2011 A recent scenario of mass wasting and its impact on the transportation in Alborz Mountains, Iran: Contribution from Geo information technology; Arabian Geosci. J. 4 1337-1349.
Glade T and Crozier M J 2005 A review of scale dependency in landslide hazard and risk analysis; Landslide Hazard Risk, https://doi.org/10.1002/9780470012659.ch3.

Hong H, Xu C and Bui D T 2015 Landslide susceptibility assessment at the Xiushui area (China) using frequency ratio model; Procedia Earth Planet. Sci. 15 513-517, https://doi.org/10.1016/j.proeps.2015.08.065.

Ilanloo M 2011 A comparative study of fuzzy logic approach for landslide susceptibility mapping using GIS: An experience of Karaj dam basin in Iran; Procedia Soc. Behav. Sci. 19 668-676.

Jaafari A, Najafi A, Pourghasemi H R, Rezaeian J and Sattarian A 2014 GIS-based frequency ratio and index of entropy models for landslide susceptibility assessment in the Caspian forest, northern Iran; Int. J. Environ. Sci. Technol. 11(4) 909-926.

Khosravi K, Nohani E, Maroufinia E and Pourghasemi H R 2016a A GIS-based flood susceptibility assessment and its mapping in Iran: A comparison between frequency ratio and weights-of-evidence bivariate statistical models with multi-criteria decision-making technique; Nat. Hazards 83(2) 1-41.

Khosravi K, Pourghasemi H R, Chapi K and Bahri M 2016b Flash flood susceptibility analysis and its mapping using different bivariate models in Iran: A comparison between Shannon's entropy, statistical index, and weighting; Environ. Monit. Assess. 188(12) 656.

Koukis G and Ziourkas C 1991 Slope instability phenomena in Greece: A statistical analysis; Bull. Int. Assoc. Eng. Geol. 43 47-60.

Lee S and Dan N T 2005 Probabilistic landslide susceptibility mapping in the Lai Chau province of Vietnam: Focus on the relationship between tectonic fractures and landslides; Environ. Geol. 48(6) 778-787.

Lee S and Pradhan B 2006 Probabilistic landslide hazards and risk mapping on Penang Island, Malaysia; J. Earth Syst. Sci. 115 661-672.

Lee S and Sambath T 2006 Landslide susceptibility mapping in the Damrei Romel area, Cambodia using frequency ratio and logistic regression models; Environ. Geol. 50 847-855.

Lee S and Pradhan B 2007 Landslide hazard mapping at Selangor, Malaysia using frequency ratio and logistic regression models; Landslides 4 33-41.

Lee Y F and Chi Y Y 2011 Rainfall-induced landslide risk at Lushan, Taiwan; Eng. Geol. 123 113-121, https://doi. org/10.1016/j.enggeo.2011.03.006.

Lefteri H T and Robert E U 1997 Fuzzy and neural approaches in engineering; A Wiley Interscience Publication.

Li L, Liu R, Pirasteh S, Chen X, Long H and Li J 2017 A novel genetic algorithm for optimization of conditioning factors in shallow translational landslides and susceptibility mapping; Arab. J. Geosci. 10 209, https://doi.org/10. 1007/s12517-017-3002-4.

Meteorological Organization of Mazandaran Province 2013 Long-term report of synoptic stations.

Metz C E 1978 Basic principles of ROC analysis; Semin. Nucl. Med. 8 283-298.

Moore I D and Burch G J 1986 Sediment transport capacity of sheet and rill flow: Application of unit stream power theory; Water Resour. Res. 22 1350-1360. 
Moore I D and Wilson J P 1992 Length-slope factors for the revised universal soil loss equation: Simplified method of estimation; J. Soil Water Conserv. 47(5) 423-428.

Moore I, Grayson R and Ladson A 1991 Digital terrain modeling: A review of hydrological, geomorphological, and biological applications; Hydrol. Process. 5 3-30.

Morrison A M 2005 Receiver operating characteristic (ROC) curve preparation: A tutorial; Boston, Massachusetts Water Resources Authority, Report ENQUAD 2005-20, 5 p.

Nezhadali E, Ouri A E and Pazira E 2013 Evaluation and Landslide hazard zonation using LIM model with GIS techniques (case study: Saein watershed. Ardabil); Int. J. Farming Allied Sci., ISSN 2322-4134.

Ozdemir H and Turoglu H 2007 Landslide susceptibility assessment using GIS and RS in the Havran river Basin (Balikesir-Turkey); In: 12th Conference of International Association for Mathematical Geology, pp. 26-31.

Ozdemir A and Altural T 2013 A comparative study of frequency ratio, weights of evidence and logistic regression methods for landslide susceptibility mapping: Sultan Mountains, SW Turkey; J. Asian Earth Sci. 64(5) 180197.

Park S, Choi C, Kim B and Kim J 2013 Landslide susceptibility mapping using frequency ratio, analytic hierarchy process, logistic regression, and artificial neural network methods at the Inje area, Korea; Environ. Earth Sci. 68(5) 1443-1464.

Pham B T, Bui D T, Pourghasemi H R, Indra P and Dholakia M B 2017 Landslide susceptibility assessment in the Uttarakhand area (India) using GIS: A comparison study of prediction capability of naïve Bayes, multilayer perceptron neural networks, and functional trees methods; Theor. Appl. Climatol. 1-19, https://doi.org/ 10.1007/s00704-015-1702-9.

Pirasteh S and Li J 2016 Landslides investigations from geoinformatics perspective: Quality, challenges, and recommendations; Geomatics Nat. Hazards Risk 1-18, https:// doi.org/10.1080/19475705.2016.1238850.

Pirasteh S and Li J 2017a Probabilistic frequency ratio (PFR) model for quality improvement of landslides susceptibility mapping from LiDAR point clouds; Geoenviron. Disaster J. 4-19, https://doi.org/10.1186/ s40677-017-0083-z.

Pirasteh S and Li J 2017b Global Changes and Natural Disaster Management: Geo-information Technologies; Springer, Berlin, ISBN 978-3-319-51843-5.

Pirasteh S, Jonathan L and Michael C 2017 Use of LiDAR-derived DEM and a stream length-gradient index approach to investigation of landslides in Zagros mountains, Iran; Geocarto Int. J., https://doi.org/10.1080/ 10106049.2017.1316779.

Pourghasemi H R, Pradhan B and Gokceoglu C 2012a Application of fuzzy logic and analytical hierarchy process (AHP) to landslide susceptibility mapping at Haraz watershed, Iran; Nat. Hazards 63(2) 965-996.

Pourghasemi H R, Mohammady M and Pradhan B 2012b Landslide susceptibility mapping using index of entropy and conditional probability models in GIS: Safarood Basin, Iran; Catena 97 71-84.

Pourghasemi H R, Jirandeh A G, Pradhan B, Xu C and Gokceoglu C 2013 Landslide susceptibility mapping using support vector machine and GIS at the Golestan Province, Iran; J. Earth Syst. Sci. 122(2) 349-369.

Pradhan B, Oh H J and Buchroithner M 2010 Weights of evidence model applied to landslide susceptibility mapping in a tropical hilly area; Geomat. Nat. Hazards $\mathbf{1}(\mathbf{3})$ 199-223.

Raghuvanshi T K, Negassa L and Kala P M 2015 GIS based grid overlay method vs. modeling approach: A comparative study for landslide hazard zonation (LHZ) in Meta Robi District of West Showa Zone in Ethiopia; Egypt. J. Remote Sens. Space Sci. 18 235-250.

Rahmati O and Pourghasemi H R 2017 Identification of critical flood prone areas in data-scarce and ungauged regions: A comparison of three data mining models; Water Resour. Manag. 31(5) 1473-1487.

Ramesh V, Phaomei T, Baskar M and Anbazhagan S 2016 Application of fuzzy gamma operator in landslide susceptibility mapping along Yercaud Ghat road section, Tamil Nadu, India; In: Geostatistical and Geospatial Approaches for the Characterization of Natural Resources in the Environment (ed.) Raju N, Springer, https://doi.org/10.1007/ 978-3-319-18663-4_82.

Regmi A D, Devkota K C, Yoshida K, Pradhan B, Pourghasemi H R, Kumamoto T and Akgun A 2013 Application of frequency ratio, statistical index, and weights-of-evidence models and their comparison in landslide susceptibility mapping in Central Nepal Himalaya; Arab. J. Geosci. 7(2) 725-742.

Renard K G, Foster G R, Weesies G A, Mccool D K and Yoder D C 1997 Predicting soil erosion by water: A guide to conservation planning with the revised soil loss equation (RUSLE); US Dept. of Agriculture, Agriculture Handbook No. 703, 404p.

Rosenfeld C L 1994 The geomorphological dimensions of natural disasters; Geomorphology 10(1) 27-36.

Ruff M and Czurda K 2008 Landslide susceptibility analysis with a heuristic approach in the Eastern Alps (Vorarlberg, Austria); Geomorphology 94(3-4) 314-324.

Safari A and Moghimi E 2009 Geomorphologic assessment of urban development and vulnerability caused by landslide in mountainous hillsides of Tehran metropolis; Phys. Geogr. Res. Q. 67 53-71.

Saha A K, Gupta R P and Arora M K 2002 GIS-based landslide hazard zonation in the Bhagirathi (Ganga) valley, Himalayas; Int. J. Remote Sens. 23 357-369.

Sahin E K, Ipbuker C and Kavzoglu T 2015 A comparison of feature and expert-based weighting algorithms in landslide susceptibility mapping; Procedia Earth Planet. Sci. 15 462-467.

Santos J G 2013 GIS-based hazard and risk maps of the Douro river basin (north-eastern Portugal); Geomat. Nat. Hazards Risk 2 90-114.

Senatore A, Mendicino G, Smiatek G and Kunstmann H 2011 Regional climate change projections and hydrological impact analysis for a Mediterranean basin in Southern Italy; J. Hydrol. 399 70-92, https://doi.org/10.1016/j. jhydrol.2010.12.035.

Shahabi H, Khezri S, Bin Ahmad B and Hashim M 2014 Landslide susceptibility mapping at central Zab basin, Iran: A comparison between analytical hierarchy process, frequency ratio and logistic regression models; Catena 115 55-70. 
Sujatha E R, Rajamanickam G V and Kumaravel P 2012 Landslide susceptibility analysis using probabilistic certainty factor approach: A case study on Tevankarai stream watershed, India; Environ. Earth Sci. 120(5) 1337-1350.

Tien Bui D, Pradhan B, Lofman O, Revhaug I and Dick O B 2012 Landslide susceptibility mapping at Hoa Binh province (Vietnam) using an adaptive neuro-fuzzy inference system and GIS; Comput. Geosci. 45 199-211.

Vakhshoori V and Zare M 2016 Landslide susceptibility mapping by comparing weight of evidence, fuzzy logic, and frequency ratio methods; Geomat. Nat. Hazards Risk $\mathbf{5}$ 1731-1752.

Van Westen C J 1997 Statistical landslide hazard analysis; Application guide, ILWIS 2.1 for Windows. ITC, Enschede, the Netherlands, pp. 73-84.

Varnes D J 1978 Slope movements: Types and processes; In: Landslide Analysis and Control, National Academy of Sciences (eds) Schuster R L and Krizek R J, Transportation Research Board Special Report, Vol. 176, pp. 11-33.

Wilson J P and Gallant J C 2000 Digital terrain analysis; In: Terrain Analysis: Principles and Applications (eds) Wilson J P and Gallant J C, Wiley, New York, pp. 1-27.

Wu Y, Chen L, Cheng C, Yin K and Torok A 2014 GIS-based landslide hazard predicting system and its real-time test during a typhoon, Zhejiang Province, Southeast China; Eng. Geol. 175 9-21.
Yalcin A 2008 GIS-based landslide susceptibility mapping using analytical hierarchy process and bivariate statistics in Ardesen (Turkey): Comparisons of results and confirmations; Catena 72 1-12.

Yalcin A, Reis S, Aydinoglu A C and Yomralioglu T 2011 A GIS-based comparative study of frequency ratio, analytical hierarchy process, bivariate statistics and logistics regression methods for landslide susceptibility mapping in Trabzon, NE Turkey; Catena 85(3) 274-287.

Ye C, Cui P, Zhang J, Li J, Meng Q, Bi X and Pirasteh S 2016 GiT-based structural geologic feature analysis of the southern segment of Longmenshan Fault Zone for earthquake evidence; J. Mountain Sci. 13(5) 906-916, https:// doi.org/10.1007/s116290153796z.

Yilmaz I 2009 Landslide susceptibility mapping using frequency ratio, logistic regression, artificial neural networks and their comparison: A case study from Kat landslides (Tokat Turkey); Comput. Geosci. 35 1125-1138.

Yusof N, Ramli M F, Pirasteh S and Shafri H Z M 2011 Landslides and lineaments mapping along the Simpang Pulai to Kg Raja highway, Malaysia; Int. J. Remote Sens. 32(14) 4089-4105.

Zadeh L A 1965 Fuzzy sets; IEEE Inf. Control 8 338-353.

Zevenbergen L W and Thorne C R 1987 Quantitative analysis of land surface topography; Earth Surf. Process. Landf. 12(1) 47-56.

Corresponding editor: NAVIN JUYAL 